

\section{Sumário}

\section{Dossier Federalismo}

Forma de Estado: Federalismo e RePartição de CompetênCIAS ...................................... 2

Carlos Bastide Horbach

IMUNIDADE RECÍPROCA E FEDERALISMO: DA CONSTRUÇÃO NORTE-AMERICANA À ATUAL POSIÇÃO Do STF

Fernando Santos Arenhart

JUSTIÇA FISCAL, PAZ TRIBUTÁRIA E OBRIGAÇõES REPUBLICANAS: UMA BREVE ANÁLISE DA DINÂMICA JuRisprudencial tributária do Supremo Tribunal Federal ............................................34

Luís Carlos Martins Alves Jr

Federalismo, estado Federalista e a REVALORIZAÇÃo do mUNicípio: UM NOVO CAMINHO PARA O SÉCULO XXI?

Antonio Celso Batista Minhoto

EfEITOS POLÍtTICO-JURÍdicos DA NÃo INSTITUCIONALIZADA PARADIPLOMACIA NO BRASIL ..........66

Gustavo de Souza Abreu

The Management of Public Natural Resource Wealth.

Paul Rose

A (IN)COMPETÊNCIA DO CONAMA PARA EDIÇÃo DE NORMAS SOBRE LICENCIAMENTO AMBIENTAL: ANÁLISE DE SUA JURIDICIDADE ...................................................................................... 118

André Fagundes Lemos

\section{Artigos sobre outros temas}

TEORÍA DE LA PRESIÓN TRIBUTARIA EN BASE A LA IGUALDAD INTERGENERACIONAL: UNA PERSPECTIVA FINANCIERA Y TRIBUTARIA DEL CASO ARGENTINO.

Luciano Carlos Rezzoagli e Bruno Ariel Rezzoagli

CRÉdito TRIBUTÁRIO: GARANTIAS, PRIVILÉGIOS E PREFERÊNCIAS.

Luís Carlos Martins Alves Júnior

Tributário - O parecer PGFN/CRJ 492/2011 e os efeitos da coisa Julgada inconstitucional em face da segurança jurídica no Estado Democrático de Direito* 
A seguranÇa jurídica administrativa na jurisprudência do Supremo Tribunal Federal: UMA ANÁLISE ACERCA DOS FUNDAMENTOS NORMATIVOS E DOS ARGUMENTOS JURÍDICOS NOS JULGAMENTOS DOS MANDADOS DE SEGURANÇA 24.781 E 25.116 195

Ana Paula Sampaio Silva Pereira

Avaliação legislativa no Brasil: apontamentos para uma nova AgENDA de PESQUiSa SoBRE O MODO DE PRODUÇÃO DAS LEIS.....................................................................229

Natasha Schmitt Caccia Salinas

Políticas públicas, DeVERES Fundamentais E CONCRETIZaÇão de DiReitos Julio Pinheiro Faro

Políticas públicas de guerra Às drogas: o ESTAdo de EXCEÇão E A transiÇão do inimigo SCHMitTiano ao homo SaCER de Agamben João Victor Nascimento Martins

NEW INSTITUTIONS FOR THE PROTECTION OF PRIVACY AND PERSONAL DIGNITY IN INTERNET COMMUNICATION - "INFORMATION BROKER", "PRIVATE CYBER COURTS" AND NETWORK OF CONTRACTS

Karl-Heinz Ladeur

RESPONSABILIDADE CIVIL DECORRENTE DE ERRO MÉDICO.

Edilson Enedino das Chagas e Héctor Valverde Santana

A atual geração de energia elétrica SEgundo a lógica de merCado e SuA Ainda CaraCTERIZAÇÃO COMO SERVIÇO PÚBLICO.

Humberto Cunha dos Santos

EMPRESAS, RESPONSABILIDADE SOCIAL E POLÍTICAS DE INFORMAÇÃo OBRIGATÓRIA NO BRASIL.....

Leandro Martins Zanitelli

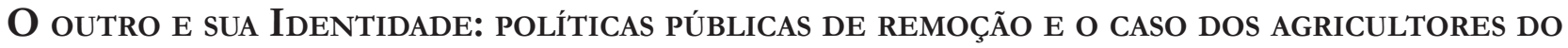
Parque Estadual da Pedra Branca/RJ.

Andreza A. Franco Câmara

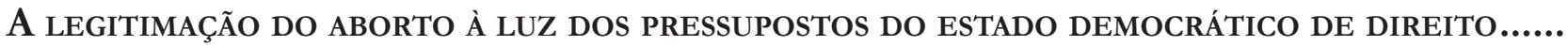

Terezinha Inês Teles Pires

JUSPOSITIVISMO, DISCRICIONARIEDADE E CONTROLE JUDICIAL DE POLÍTICAS PÚBLICAS NO DIREITO BRASILEIRO

Guilherme Valle Brum

A governança transnacional ambiental na Rio +20 . Paulo Márcio Cruz e Zenildo Bodnar 
O QUE É UMA BOA TESE DE DOUTORADO EM DiREITO? UMA ANÁlise A PARTIR DA PRÓPRIA PERCEPÇÃO DOS PROGRAMAS ............................................................................424

Nitish Monebhurrun e Marcelo D. Varella

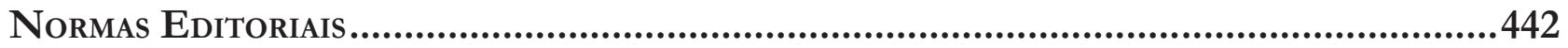

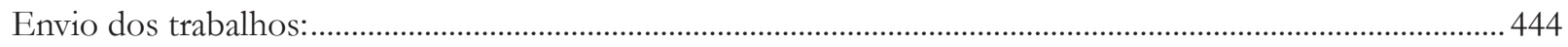




\title{
Crédito tributário: garantias, privilégios e preferências
}

\author{
Tax credit: guarantees, privileges and \\ preferences*
}

Luís Carlos Martins Alves Júnior**

\section{Resumo}

Neste texto será feita uma abordagem do instituto normativo do crédito tributário, especialmente no tocante às suas garantias, privilégios e preferências. Nesta análise serão visitados preceitos contidos no Código Tributário Nacional (Lei n. 5.172, de 25.10.1966), além de apreciadas algumas decisões judiciais do Superior Tribunal de Justiça e do Supremo Tribunal Federal. O texto analisa institutos normativos relevantes para a adequada compreensão do crédito tributário, como a obrigação tributária, o fato gerador e o lançamento tributário. Na construção deste texto, além dos dispositivos legais, evocou-se o magistério tributário da doutrina brasileira, bem como se ventilou acerca dos aspectos socialmente maléficos do tradicional hábito de não cumprimento das leis, sejam fiscais ou não, que vicejam em solo brasileiro.

Palavras-chave: Direito tributário. Código Tributário Nacional. Crédito tributário. Precedentes judiciais. Magistério doutrinário.

\section{Abstract}

This paper will be a normative approach of the institute tax liability, especially as regard its enforcement, privileges and preferences. This analysis Will be visitede precepts contained in the Brazilian Tax Code (Law n. 5,172, of 10.25.1966), and enjoyed some judgments of the Brazilian Superior Court and the Brazilian Supreme Court. This paper analyzes regulatory institutes relevant to a proper understanding of the tax, as the tax liability, the taxable event, the tax assessment. In the construtcion of this paper, in addition of the legal provisions, raised up the teaching of the doctrine Brazilian tax as well as fanned about socially harmful aspects of the traditional habito $\mathrm{f}$ not complyng with the laws, wheter or not tax, which grow up on Brazilian soil.

Keyords: Tax law. Brazilian Tax Code. Tax liability. Judicial precedente. Doctrinal magisterium.

* Recebido em 25/04/2013 Aprovado em 13/08/2013

** Doutor em Direito pela UFMG. Procurador da Fazenda Nacional. Professor do Programa de Mestrado e Doutorado em Direito do UNICEUB. Email: lcmartinsalves@gmail.com

\section{INTRODUÇÃo}

O presente texto analisa os institutos normativos das garantias, dos privilégios e das preferências do crédito tributário. Nesta análise, além dos aludidos institu- 
tos, serão visitadas figuras normativas que gravitam ao redor do crédito tributário, como sucede com a obrigação tributária, com o seu fato gerador, com o lançamento tributário e com a dinâmica da própria administração tributária.

A justificativa do tema decorre da relevância do instituto do crédito tributário para a dinâmica fiscal e econômica brasileira, pois esse instituto normativo consiste na autorização para as administrações fazendárias cobrarem, ou dos contribuintes, ou dos responsáveis, os tributos moral e legalmente devidos.

A finalidade da análise consiste em apresentar, tanto nos aspectos estáticos (textos normativos), quanto nos dinâmicos (decisões judiciais), bem como nos acadêmicos (magistério doutrinário), a situação real do crédito tributário no Brasil, enfocando os seus principais ângulos. O trabalho pretende revelar algumas facetas do crédito tributário.

\section{O tributo, A LeI E A DEMOCRACIA ${ }^{1}$}

Onde se ergue o poder do Estado se projeta a sombra do poder de tributar, na clássica passagem de Aliomar Baleeiro. ${ }^{2}$ Conquanto seja o poder de tributar uma decorrência do poder do Estado, imensas são as dificuldades que os Fiscos, federal, estaduais ou municipais, sofrem na cobrança dos seus créditos. ${ }^{3}$ Ocorre que o crédito tributário, apesar de todas as suas garantias e privilégios legais, ${ }^{4}$ sofre do mesmo mal que acomete o crédito em geral neste País: a dificuldade em ser recuperado. ${ }^{5}$

Neste complexo Brasil, as leis, os contratos, as sentenças ou os decretos não são "levados muito a sério",

1 Na clássica obra "O Mercador de Veneza", de William Shakespeare, o mercador e cristão Antônio empenha uma libra de sua carne, como cláusula penal, na hipótese de não cumprimento do contrato que assinara e se comprometera junto ao judeu Shylock. O contrato é assinado em Veneza, onde deverá ser executada a aludida cláusula penal, tendo em vista o descumprimento da promessa contratual avençada. O próprio Antônio, às vésperas da execução da citada cláusula penal, compreendia que o Doge (chefe político) da República de Veneza não poderia deixar de atender à reivindicação do judeu Shylock e deveria permitir o integral cumprimento do contrato. É que, se acaso o Doge não garantisse a fiel execução do contrato e de sua respectiva cláusula penal, a justiça do Estado ficaria comprometida e Veneza deixaria de ser um local seguro para os negócios, uma vez que os contratos não seriam mais protegidos pelas leis nem pelos juízes. Nessa peça teatral, em Veneza, contrato assinado era contrato cumprido. Todos sabem o resultado do julgamento acerca do cumprimento dessa mencionada "cláusula penal": se o judeu exercesse o seu direito de execução sofreria pena de morte, pois, segundo as leis venezianas, estava impedido de derramar uma gota de sangue cristão. Pois bem, se na Veneza shakespeariana o crédito era sagrado, em nosso País ele é profano. SHAKESPEARE, William. O mercador de Veneza: 1596. São Paulo: Martins Fontes, 2006.

2 BALEEIRO, Aliomar. Limitações constitucionais ao poder de limitar. 7. ed. Atualizada por Misabel Abreu Machado Derzi. Rio de Janeiro: Forense, 2005.

3 A imagem histórica dos "cobradores de impostos" não é das mais atrativas. Esse aludido caráter profano do crédito tributário se torna mais evidente a partir das Sagradas Escrituras, pois os "publicanos - cobradores de impostos" estavam, segundo os padrões religiosos da época da anunciação evangélica, no rol dos grandes pecadores. BÍBLIA Sagrada. Novo Testamento. Mateus, capítulo 21, versículo 31; Lucas, capítulo 19, versículos 1-9.

4 BRASIL. Lei n. 5.172, de 25.10.1966. Código Tributário Nacional, Capítulo VI - Garantias e Privilégios do Crédito Tributário, arts. 183 a 193. Local: Editora, ano.

5 Com efeito, o IPEA - Instituto de Pesquisa Econômica e Aplicada -, em pesquisa realizada entre novembro de 2009 e fevereiro de 2011, divulgada em janeiro de 2012, revelou que somente 2,8\% das execuções fiscais federais resultam em algum leilão judicial, com ou sem êxito. Do total de processos, em apenas $0,3 \%$ dos casos o pregão gera recursos suficientes para satisfazer integralmente o débito, enquanto que a adjudicação dos bens do executado extingue a dívida em $0,4 \%$ dos casos. $\mathrm{Na}$ aludida pesquisa, o IPEA, por meio de entrevistas junto aos órgãos do Judiciário, percebeu a pouca efetividade dos leilões, dada a sua burocrática complexidade, de modo que muitas das varas federais implantadas nos últimos cinco anos anteriores a essa pesquisa jamais realizaram qualquer pregão. O IPEA revelou que, em decorrência das execuções fiscais, 25,8\% implicam no pagamento integral da dívida; em 36,8\% ocorrem a extinção pelo reconhecimento de decadência ou de prescrição; $18,8 \%$ decorrem do cancelamento da inscrição do débito e 13\% de sua remissão. Segundo o IPEA, em regra, as execuções fiscais ou fracassam absolutamente, ou recuperam integralmente o débito. O IPEA revelou que a taxa de êxito do executado, via embargos ou exceção de pré-executividade, chega a 22,5\%. Daí porque o IPEA ter indicado que não vale a pena, no aspecto estritamente econômico, ajuizar execuções fiscais abaixo de $\mathrm{R} \$ 20.000,00$. Todavia, continuou o IPEA, essa implantação de novo piso deveria vir acompanhada de implementação de medidas de redução do risco moral (moral hą̧ard) associado ao não pagamento de tributos. BRASIL. Instituto de Pesquisa Econômica e Aplicada. Custo e tempo do processo de execução fiscal promovido pela Procuradoria Geral da Fazenda Nacional (PGFN). Comunicados do IPEA, Brasília, n. 127, 2012. Disponível em: <www.ipea.gov.br>. Acesso em: 
tampouco se pode falar em um "império do direito". ${ }^{6}$ Neste gigantesco País, é difícil o respeito às leis, ${ }^{7}$ visto que não são poucos os refratários ao cumprimento de suas obrigações e deveres. ${ }^{8}$ É traço atávico dos brasileiros.

Essa lamentável tradição brasileira de não cumprimento das leis e de costumeiro desrespeito ao Direito deita suas raízes no período colonial. A partir daquele cenário social e político, deixar de recolher os tributos à Coroa lusitana significava um ato de desobediência civil e de insubmissão ao poderio português. Assim, enquanto o Brasil esteve sob o domínio de Portugal, o não pagamento de impostos poderia ter sentido "político". ${ }^{10} \mathrm{Na}$ longa experiência brasileira, o Estado tem sido maior e mais importante que a sociedade. ${ }^{11}$

Nada obstante, cuide-se que houve momentos em nossa história que o não pagamento de tributos poderia ser justificado como ato legítimo em oposição a um Estado ilegítimo, a partir de 5 de outubro de 1988, com o pleno restabelecimento das franquias democráticas e com a consolidação do Estado de Direito, esse tipo de postura passou a ser moralmente inaceitável e juridicamente inadmissível. Com efeito, desde a promulgação da vigente e reinante Constituição da República, a nenhuma pessoa natural ou jurídica é dado o direito moral e legítimo de não pagar os tributos, salvo se obtiver expressa autorização judicial, legislativa ou administrativa. ${ }^{12}$

Ninguém tem o direito de não pagar as próprias dívidas fiscais. Ninguém tem o direito de não honrar com os próprios compromissos tributários. É um dever cívico o pagamento dos débitos. É obrigação republicana cobrar dos devedores. É um truísmo, mas, no Estado Democrático de Direito, todo aquele que não cumpre com o dever de cooperação social, dentro de suas capacidades e possibilidades, sobrecarrega os demais. ${ }^{13}$ Assim, sempre que algum contribuinte, seja pessoa natural ou jurídica, deixar de pagar os tributos legalmente devidos, ele sobrecarregará com ônus excessivo os que estão honrando com os compromissos e deveres fiscais. ${ }^{14}$

Nos regimes políticos democráticos, ninguém tem o direito - jurídico ou moral - de não pagar os tributos devidos, salvo nas situações excepcionais e explicitamente reconhecidas pelo próprio Estado (legislador, administrador ou julgador). ${ }^{15}$ E por que no Estado Democrático de Direito o não pagamento de tributos não pode ser visto como ato legítimo de desobediência civil? A resposta consiste no fato de que a desobediência civil pressupõe que os legítimos canais de manifestação das insatisfações estejam obstruídos. ${ }^{16}$ Nas

6 "Império do Direito" e "Levando os Direitos a sério", como todos sabem, são algumas expressões que se tornaram famosas graças ao magistério doutrinário de Ronald Dworkin, um dos maiores jusfilósofos de todos os tempos, recentemente falecido (14.2.2013), autor de importantes livros: The Philosofal os Law, Taking Rights Seriously, Law's Empire, A Matter of Principle, Life's Dominion, Sovereign Virtue, Is Democracy Possible Here?, Freedom's Law, Justice in Robes, A Badly Flawed Election: Debating Bush v. Gore, The Supreme Court Phalanx, Justice for Hedgebogs e Reason and Imagination: The Selected Correspondence of Learned Hand. Quase todos esses livros estão disponíveis em traduções para o português.

7 Essa combinação é explosiva: falta de ética das pessoas aliada à falta de responsabilidade dos agentes estatais. Eis uma das causas de nossos problemas de convivência social e de desobediência aos mandamentos normativos que devem regular a vida coletiva de modo civilizado e humanizado. "Ou restaura-se a moralidade, ou locupletemo-nos todos". Frase de Stanislaw Ponte Preta, pseudônimo de Sérgio Porto. PRETA, Stanislaw Ponte. O melhor de Stanislaw Ponte Preta. São Paulo: José Olympio, 2011.

8 E essa tradição de desobediência não se restringe apenas ao campo fiscal. Tomemos, à guisa de exemplo, o que sucede em relação às regras de trânsito, especialmente nas grandes cidades brasileiras. Infelizmente nas nossas metrópoles, onde deveria reinar a urbana civilidade, vivenciamos verdadeira selvageria e irracionalidade caótica no trânsito, pois não são poucos os que desrespeitam os mais comezinhos padrões de convivência. A razão dessa situação caótica não está na ausência de leis ou regulamentos, mas de educação cívica das pessoas e de incompetência dos poderes estatais. Ou a lei deve valer para todos, ou não vale para ninguém. No Brasil, infelizmente, para poucos, especialmente para os poderosos, as leis somente servem se lhes forem convenientes. Ora a civilidade de um povo se mede também pelo respeito e obediência às leis e às instituições.

9 HOLANDA, Sérgio Buarque de. Raízes do Brasil. 26. ed. São Paulo: Companhia das Letras, 1995.

10 Tenha-se que com a chegada da familia real portuguesa, instalando no Brasil a sede do império lusitano, tem início uma nova fase na tributação brasileira. Todavia, foi mantido o eixo de pesada carga fiscal, decorrência de um culto exagerado que se presta ao Estado, como assinala Arnaldo Godoy. GODOY, Arnaldo Sampaio de Moraes. História da tributação no período joanino: 1808-1821. Brasília: ESAF, 2008. p. 147.

11 FAORO, Raymundo. Os donos do poder: formação do patronato brasileiro. 7. ed. Rio de Janeiro: Globo, 2001. p. 163-275.

12 Eis a imensa responsabilidade ética dos procuradores fiscais. Com esteio no postulado republicano e em homenagem ao princípio da igualdade de todos perante a lei, os procuradores fiscais têm o dever jurídico e moral de cobrar todos os tributos que estejam sob sua responsabilidade.

13 RAWLS, John. Uma teoria da justiça. Trad. Almiro Piseta e Lenita Esteves. São Paulo: Martins Fontes, 2000.

14 TIPKE, Klaus. Moral tributária do Estado e dos contribuintes. Trad. Luiz Dória Furquim. Porto Alegre: Sergio Antonio Fabriz, 2012.

15 NABAIS, José Casalta. O dever fundamental de pagar impostos: contributo para a compreensão constitucional do estado fiscal contemporâneo. Coimbra: Almedina, 1998.

16 COSTA, Nelson Nery. Teoria e realidade da desobediência civil. Rio de Janeiro: Forense, 1990. 
democracias, insatisfeitos, incomodados e injustiçados podem mudar a situação dentro de procedimentos legítimos e pacíficos, usando dos instrumentos jurídicos e políticos disponíveis. ${ }^{17}$

Nas democracias, é possível, dentro da lei, mudar o sistema social e político. É possível mudar a própria lei. ${ }^{18}$ Nos regimes políticos democráticos, plurais e abertos, como tem sido o brasileiro desde 1988, é possível disputar e ganhar eleições, sejam os partidos da situação, sejam os de oposição. Nas sociedades abertas e democráticas, é possível conquistar as mentes e os corações das pessoas por meio do diálogo, da palavra, do convencimento, da razão e da verdade. ${ }^{19}$

$\mathrm{Na}$ democracia, o indivíduo, ser humano e humanizado, deve ter vez, voz e voto. ${ }^{20}$ No regime de liberdades democráticas, a divergência de opiniões e o dissenso ideológico devem ser seriamente considerados e efetivamente respeitados. As maiorias dominantes não têm o direito de extinguir as minorias. ${ }^{21}$ Nessa perspectiva, nos regimes democráticos nos quais deve reinar o Estado de Direito, não pagar os tributos devidos viola o pacto social fundante da coletividade. É indecente furtar-se, sem justo e válido título, ao cumprimento dos deveres cívicos e das obrigações tributárias.

Nas democracias legítimas e nas repúblicas decentes, as leis devem ser respeitadas e obedecidas por todos: sejam governantes poderosos ou humildes cidadãos, sejam ricos ou pobres, homens ou mulheres, brancos ou negros, crentes ou ateus. Ou seja, nos regimes democráticos e republicanos, todos, independentemente de suas características, devem pautar suas ações e seus comportamentos em conformidade com o direito e com a justiça. Ninguém deve estar acima das leis.

No Brasil republicano e democrático, os tributos devidos, legalmente válidos e moralmente justos, devem ser cobrados. Não sem razão que o recepcionado Código Tributário Nacional, ${ }^{22} \mathrm{em}$ seu artigo $3^{\circ}$, dispõe que a atividade administrativa fiscal é plenamente vinculada, ou seja, não depende da vontade, da discricionariedade ou dos caprichos da autoridade fiscal à cobrança de tributos. É um imperativo legal e moral. Tributo devido é tributo que se deve cobrar/pagar.

Mas qual tributo se deve pagar? Como se sabe que se deve pagar um tributo? Quem deve pagar o tributo? Quanto se deve pagar? Quem pode cobrar esse tributo devido? As respostas a essas indagações necessitam que visitemos o sentido jurídico e o alcance normativo de "obrigação tributária", ${ }^{23}$ de "crédito tributário" 24 e da própria dinâmica da "administração tributária". ${ }^{25}$ Após essas visitas, surpreenderemos o tema específico desta intervenção: as garantias e os privilégios do crédito tributário. ${ }^{26}$

\section{A ObRIGAÇÃo E O CRÉDItO tRIBUTÁRIO}

O crédito tributário é o direito que possui a Fazenda Pública, após o lançamento válido, de exigir o pagamento de determinado tributo. Nos termos do art. 142, CTN, a constituição do crédito tributário pressupõe o lançamento, que vem a ser:

[...] o procedimento administrativo tendente a verificar a ocorrência do fato gerador da obrigação correspondente,

17 HABERMAS, Jürgen. Jürgen. Direito e democracia: entre facticidade e validade. Trad. Flávio Beno Siebeneichler. Rio de Janeiro: Tempo Brasileiro, 2003.

18 BOBBIO, Norberto. O futuro da democracia. Trad. Marco Aurélio Nogueira. São Paulo: Paz e Terra, 2000.

19 POPPER, Karl. A sociedade aberta e seus inimigos. Trad. Milton Amado. São Paulo: Itatiaia, 1987.

20 MAGALHÃES, José Luiz Quadros de. Poder municipal: paradigmas para o estado constitucional brasileiro. Belo Horizonte: Del Rey, 1997.

21 KELSEN, Hans. A democracia. Trad. Ivone Castilho Benedeti e outros. São Paulo: Martins Fontes, 1993.

22 CTN, Art. $3^{\circ}$. Tributo é toda prestação pecuniária compulsória, em moeda ou cujo valor nela se possa exprimir, que não constitua sanção de ato ilícito, instituída em lei e cobrada mediante atividade administrativa plenamente vinculada.

23 CTN, Arts. 113 a 138.

24 CTN, Arts. 139 a 193.

25 CTN, Arts. 194 a 208.

26 CTN, Arts. 183 a 193. 
determinar a matéria tributável, calcular o montante do tributo devido, identificar o sujeito passivo e, sendo o caso, propor a aplicação da penalidade cabível.

Por expressa determinação legal, “[...] a atividade de lançamento é vinculada e obrigatória, sob pena de responsabilidade funcional”. (CTN, art. 142, parágrafo único).

Veja-se que a lei determina que somente o lançamento dá à Fazenda Pública o direito de cobrar o crédito tributário. Isso não significa que somente se houver o lançamento é que surge o dever de pagar o tributo. Com efeito, a cobrança do crédito tributário requer o prévio lançamento; mas é possível que o sujeito passivo da obrigação tributária pague a dívida fiscal antes de ocorrido o lançamento administrativo, pela simples existência do fato gerador, como preceitua o art. 150, caput e $\int 1^{\circ}$, do CTN.

Nos artigos 113 e 114, do mesmo código, estão enunciados os sentidos normativos de "obrigação tributária" e de "fato gerador". Esses temas foram objeto de considerações dos maiores nomes do direito tributário nacional, tendo em vista as confusões terminológicas e normativas decorrentes de sua inadequada compreensão e aplicação. Eis alguns desses geniais tributaristas: Aliomar Baleeiro, ${ }^{27}$ Rubens Gomes de Sousa, ${ }^{28}$ Amílcar de Araújo Falcão, ${ }^{29}$ Souto Maior Borges, ${ }^{30}$ Alfredo Augusto Becker, ${ }^{31}$ Geraldo Ataliba, ${ }^{32}$ Paulo de Barros Carvalho, ${ }^{33}$ Sacha Calmon, ${ }^{34}$ e Misabel Derzi, ${ }^{35}$ dentre outros destacados nomes da justributarística brasileira.

Nada obstante as eventuais disceptações doutrinárias, esses termos encontram-se consagrados normativamente, inclusive com reconhecimento constitucional, como se vê nos dispositivos relativos aos tributos e às contribuições sociais (CF, arts. 145 a 156; e art. 195, itens). O "fato gerador" dá ensejo à "obrigação tributária" e ao seu consequente "crédito tributário"; mas, insista-se, somente com o "lançamento tributário" surge o direito de a Fazenda Pública cobrar o tributo devido.

Quanto ao fato gerador da obrigação tributária, há o enunciado contido no parágrafo único do art. 116, CTN, acrescentado pela Lei Complementar n. 104/2001, que preceitua:

[...] a autoridade administrativa poderá desconsiderar atos ou negócios jurídicos praticados com a finalidade de dissimular a ocorrência do fato gerador do tributo ou a natureza dos elementos constitutivos da obrigação tributária, observados os procedimentos a serem estabelecidos em lei ordinária. ${ }^{3637}$

O aludido preceito normativo foi atacado via Ação Direta de Inconstitucionalidade (ADI) n. 2.446, proposta perante o Supremo Tribunal Federal (STF), pela Confederação Nacional da Indústria (CNI). ${ }^{38}$ O Tribunal ainda não se pronunciou sobre a validade jurídica do objurgado dispositivo normativo. Esse julgamento é de vital importância para as administrações tributárias, pois se trata de um mandamento de moralidade jurídica.

Com efeito, é postulado universal do direito dos povos civilizados que ninguém pode se beneficiar da própria torpeza. Em matéria tributária, devem ser draconianas as consequências normativas e administrativas para todos que visem fraudar a verdade fiscal. ${ }^{39} \mathrm{~A}$ citada determinação legal consiste nisto: permitir que a fiscalização tributária não considere atos fraudulentos ou que visem, de modo aparentemente legal, adulterar a legitimidade da

27 BALEEIRO, Aliomar. Direito tributário brasileiro. 11. ed. Atualizado por Misabel Derzi. Rio de Janeiro: Forense, 2005.

28 SOUSA, Rubens Gomes. Compêndio de legislação tributária. São Paulo: Resenha Tributária, 1975.

29 FALCÃO, Amílcar de Araújo. O fato gerador da obrigação tributária. São Paulo: RT, 1973.

30 BORGES, José Souto Maior. Lançamento tributário. 2. ed. São Paulo: Malheiros, 1999.

31 BECKER, Alfredo Augusto. Teoria geral do direito tributário. 3. ed. São Paulo: Lejus, 1998.

32 ATALIBA, Geraldo. Hipótese de incidência tributária. 5. ed. São Paulo: Malheiros, 1992.

33 CARVALHO, Paulo de Barros. Dreito tributário: fundamentos jurídicos da incidência. 7. ed. São Paulo: Saraiva, 2009.

34 CALMON, Sacha. Teoria geral do tributo e da exoneração tributária. São Paulo: RT, 1982.

35 DERZI, Misabel. Direito tributário, direito penal e tipo. 2.ed. São Paulo: RT, 2007.

36 ROLIM, João Dácio. Normas antielisivas tributárias. São Paulo: Dialética, 2001.

37 PEREIRA, Cesar A. Guimarães. Elisão tributária e função administrativa. São Paulo: Dialética, 2001.

38 BRASIL. Supremo Tribunal Federal. Ação direta de inconstitucionalidade n. 2.446. Requerente: Confederação Nacional da Indústria. Requeridos: Presidente da República e Congresso Nacional. Relatora originária: Ministra Ellen Gracie. Relatora redistribuída: Ministra Cármen Lúcia. Local, 2001.

39 GODOI, Marciano Seabra de. Fraude a la ley y conflicto em la aplicación de las leyes tributarias. Madrid: Instituto de Estudios Fiscales, 2005. 
tributação. Para a adequada solução desse problema normativo, o STF deverá investigar as circunstâncias fáticas que deram ensejo a esse questionado preceito normativo, bem como perspectivar a finalidade desse mandamento jurídico em sintonia com os dispositivos constitucionais e com os valores protegidos pelo sistema jurídico. ${ }^{40} 41$

De efeito, o STF e todos os demais órgãos judiciários brasileiros, sejam singulares, sejam colegiados, devem sempre pautar as decisões com esteio no ordenamento jurídico e nas práticas normativas válidas e intersubjetivamente aceitáveis. As decisões judiciais em matéria tributária devem ser em absoluta conformidade com o ordenamento jurídico, pois não é dado à autoridade judicial, no exercício de sua competência, desconsiderar os preceitos normativos. ${ }^{42}$

A fidelidade aos mandamentos jurídicos extraídos direta ou indiretamente da Constituição, das leis, dos tratados e dos demais provimentos normativos é a principal garantia decorrente do princípio da segurança jurídica. ${ }^{43} 45$ Eis a razão de o sistema tributário nacional ser tão extensivo e, ante esse caráter amiúde analítico, tornar-se tão complexo e problemático, pois além de um feixe de preceitos tributários contidos na Constituição, tem-se invencível legislação federal, estadual, distrital e municipal regulando o fenômeno tributário. ${ }^{46}$

Volta-se à obrigação e ao crédito tributário. No CTN, art. 119, está disposto que o sujeito ativo da obrigação tributária é a pessoa jurídica de direito público, titular da competência para exigir o seu cumprimento. A pessoa obrigada ao pagamento de tributo ou penalidade pecuniária é o sujeito passivo da obrigação. Esse sujeito passivo pode ser o próprio contribuinte ou o responsável tributário (CTN, arts. 121 e 122).

No art. 123 do CTN há relevante garantia fiscal, uma vez que preceitua que as convenções particulares não podem ser opostas à Fazenda Pública para modificar a definição legal do sujeito passivo das respectivas obrigações tributárias, salvo exceção legal específica. Ainda no plano da normatização da sujeição passiva, os arts. 124 a 127 disciplinam os institutos da solidariedade, da capacidade e do domicílio tributário, quase sempre em sentido favorável ao cumprimento dos deveres fiscais dos contribuintes ou responsáveis. Cuidese que, no tocante à solidariedade tributária, por exemplo, não há que se falar em benefício de ordem, de modo que o Fisco pode escolher entre os sujeitos passivos os mais adequados para a solvência do crédito.

Também não podem ser opostas ao Fisco as eventuais irregularidades, informalidades ou incapacidades dos sujeitos passivos, como forma de escapar do cumprimento das obrigações tributárias. No concernente ao domicílio tributário do sujeito passivo, como garantia ao crédito, a legislação permite à autoridade administrativa que recuse o domicílio eleito, quando impossibilite ou dificulte a arrecadação ou a fiscalização do tributo (art. 127, $\int 2^{\circ}$ do CTN).

$\mathrm{Na}$ Constituição Federal, art. $150, \sqrt{ } 7^{\circ}$, foi dado reforço normativo ao instituto da responsabilidade tributária, quando dispôs que :

[...] a lei poderá atribuir a sujeito passivo de obrigação tributária a condição de responsável pelo pagamento de imposto ou contribuição, cujo fato gerador deva ocorrer posteriormente, assegurada a imediata e preferencial restituição da quantia paga, caso não se realize o fato gerador presumido.

No CTN, a responsabilidade tributária está regulada no capítulo V, arts. 128 a 138. O tema acerca da validade e da conveniência da técnica fiscal da substituição tributária, corolário da responsabilidade tributária, tem sido objeto de vários questionamentos judiciais, inclusive com manifestações do Supremo Tribunal Federal.

40 TORRES, Ricardo Lobo. Normas de interpretação e integração do direito tributário. 4. ed. Rio de Janeiro: Renovar, 2006.

41 ANDRADE, José Maria Arruda de. Interpretação da norma tributária. São Paulo: MP, 2006.

42 GAMA, Tácio Lacerda. Competência tributária: fundamentos para uma teoria da nulidade. São Paulo: Noeses, 2009.

43 ÁVILA, Humberto. Segurança jurídica: entre permanência, mudança e realização no direito tributário. São Paulo: Malheiros, 2011.

44 TORRES, Heleno Taveira. Direito constitucional tributário e segurança jurídica. São Paulo: RT, 2011.

45 ANDRADE, Fábio Martins de. Modulação em matéria tributária: o argumento pragmático ou consequencialista de cunbo econômico e as decisões do STF. São Paulo: Quartier Latin, 2011.

46 CARrAZA, Roque Antônio. Curso de direito constitucional tributário. 25. ed. São Paulo: Malheiros, 2009. 
O Tribunal iniciou o julgamento das ADIs n. $2.675^{47}$ e n. 2.777, ${ }^{48} \mathrm{em} 26$ de novembro de 2003, havendo até o presente momento 10 votos prolatados, com cinco pela procedência e cinco pela improcedência.

No aludido julgamento, faltava colher o voto do ministro Ayres Britto; mas, em face de sua aposentadoria, é de se aguardar a posse de novo ministro para que essas ADIs sejam finalmente decididas. Nada obstante, o Tribunal reconheceu a repercussão geral de questões relativas à substituição tributária nos autos dos RREE $596.832,{ }^{49} 593.849^{50}$ e $598.677 . .^{51}$

Esse tema não é novo para o STF. No julgamento da ADI n. 1.851, ${ }^{52}$ o Tribunal chancelou a técnica segundo a qual o "fato gerador presumido" é válido e que a sua devolução preferencial ocorre na hipótese de não realização. O Tribunal decidirá, nos aludidos feitos, se, na hipótese de base de cálculo inferior à presumida, é lícito ao contribuinte a restituição proporcional.

Não há expressa vedação constitucional a essa possibilidade, cabendo ao legislador fiscal a conveniência desse tipo de medida. O Tribunal deve fazer juízo de "legalidade jurídica", em vez de juízo de "conveniên-

47 BRASIL. Supremo Tribunal Federal. Supremo Tribunal Federal. Ação direta de inconstitucionalidade n. 2.675. Requerente: Governador do Estado de Pernambuco. Requerida: Assembléia Legislativa do Estado de Pernambuco. Relator originário: Ministro Carlos Velloso. Relator: redistribuído: Ministro Ricardo Lewandowski. Local, 2002.

48 BRASIL. Supremo Tribunal Federal. Ação direta de inconstitucionalidade n. 2.777. Relatoria originária Ministro Sydney Sanches. Relatoria redistribuída Ministro Teori Zavascki. Requerente: Governador do Estado de São Paulo. Requerida: Assembleia Legislativa do Estado de São Paulo. Local, 2002.

49 BRASIL. Supremo Tribunal Federal. Recurso Extraordinário n. 596.832. Recorrentes: Posto de Gasolina Rei de Mesquita Ltda e outros. Recorrida: União Federal (Fazenda Nacional). Relator: Ministro Marco Aurélio. Local, 2009. Ementa do acórdão do reconhecimento da repercussão geral no RE 596.832: "PIS E COFINS - SUBSTITUIÇÃO TRIBUTÁRIA - ARTIGO 150, § 7", DA CONSTITUIÇÃO FEDERAL - RECOLHIMENTO A MAIOR - DEVOLUÇÃO - ADINS No 2.675-5/PE E 2.777-8/ SP - VOTAÇÃO EMPATADA - RECURSO EXTRAORDINÁRIO EM PROCESSO SUBJETIVO - Possui repercussão geral a controvérsia sobre o cabimento da restituição dos valores recolhidos a maior a título de PIS e COFINS quando a base de cálculo inicialmente estimada for superior à base de cálculo real, considerado o regime de substituição tributária".

50 BRASIL. Supremo Tribunal Federal. Recurso Extraordinário n. 593.849. Recorrente: Parati Petróleo Ltda. Recorrido: Estado de Minas Gerais. Relator: Ministro Ricardo Lewandowski. Local, 2008. Ementa do acórdão que reconheceu a repercussão geral: “CONSTITUCIONAL. TRIBUTÁRIO. ICMS. RESTITUIÇÃO DA DIFERENÇA DO IMPOSTO PAGO A MAIS NO REGIME DE SUBSTITUIÇÃO TRIBUTÁRIA. BASE DE CÁLCULO PRESUMIDA E BASE DE CÁLCULO REAL. ART. 150, § 7², DA CF. ADI 2.675/PE, REL. MIN. CARLOS VELLOSO E ADI 2.777/SP, REL. MIN. CEZAR PELUSO, QUE TRATAM DA MESMA MATÉRIA E CUJO JULGAMENTO JÁ FOI INICIADO PELO PLENÁRIO. EXISTÊNCIA DE REPERCUSSÃO GERAL”. 51 BRASIL. Supremo Tribunal Federal. Recurso Extraordinário n. 598.677. Recorrente: Estado do Rio Grande do Sul. Recorrida: Juliana Enderle Fontoura. Relator: Ministro Dias Toffoli. Local, 2009. Ementa do acórdão que reconheceu a repercussão geral: "EMENTA DIREITO TRIBUTÁRIO. ICMS. OPERAÇÕES INTERESTADUAIS. REGIME DE PAGAMENTO ANTECIPADO SEM SUBSTITUIÇÃO TRIBUTÁRIA. DECRETO ESTADUAL. FATO GERADOR DO TRIBUTO. COBRANÇA ANTECIPADA. EXISTÊNCIA DE REPERCUSSÃO GERAL”.

52 BRASIL. Supremo Tribunal Federal. Ação direta de inconstitucionalidade n. 1.851. Requerente: Confederação Nacional do Comércio. Requerido: Estado de Alagoas. Relator: Ministro Ilmar Galvão. Local, 1998. Ementa do acórdão: "TRIBUTÁRIO. ICMS. SUBSTITUIÇÃO TRIBUTÁRIA. CLÁUSULA SEGUNDA DO CONVÊNIO $13 / 97$ E $\int S 6^{\circ}{ }^{\circ}$ E $7 .^{\circ}$ DO ART. 498 DO DEC. N. ${ }^{\circ}$ 35.245/91 (REDAÇÃO DO ART. $1 .^{\circ}$ DO DEC. N. ${ }^{\circ}$ 37.406/98), DO ESTADO DE ALAGOAS. ALEGADA OFENSA AO $\int 7 .^{\circ}$ DO ART. 150 DA CF (REDAÇÃO DA EC 3/93) E AO DIREITO DE PETIÇÃO E DE ACESSO AO JUDICIÁRIO. Convênio que objetivou prevenir guerra fiscal resultante de eventual concessão do benefício tributário representado pela restituição do ICMS cobrado a maior quando a operação final for de valor inferior ao do fato gerador presumido. Irrelevante que não tenha sido subscrito por todos os Estados, se não se cuida de concessão de benefício (LC 24/75, art. 2. ${ }^{\circ}$, INC. 2. ${ }^{\circ}$ ). Impossibilidade de exame, nesta ação, do decreto, que tem natureza regulamentar. A EC n. ${ }^{\circ}$ 03/93, ao introduzir no art. 150 da $\mathrm{CF} / 88$ o $\int 7 .^{\circ}$, aperfeiçoou o instituto, já previsto em nosso sistema jurídico-tributário, ao delinear a figura do fato gerador presumido e ao estabelecer a garantia de reembolso preferencial e imediato do tributo pago quando não verificado o mesmo fato a final. A circunstância de ser presumido o fato gerador não constitui óbice à exigência antecipada do tributo, dado tratar-se de sistema instituído pela própria Constituição, encontrando-se regulamentado por lei complementar que, para definir-lhe a base de cálculo, se valeu de critério de estimativa que a aproxima o mais possível da realidade. A lei complementar, por igual, definiu o aspecto temporal do fato gerador presumido como sendo a saída da mercadoria do estabelecimento do contribuinte substituto, não deixando margem para cogitar-se de momento diverso, no futuro, na conformidade, aliás, do previsto no art. 114 do CTN, que tem o fato gerador da obrigação principal como a situação definida em lei como necessária e suficiente à sua ocorrência. $\mathrm{O}$ fato gerador presumido, por isso mesmo, não é provisório, mas definitivo, não dando ensejo a restituição ou complementação do imposto pago, senão, no primeiro caso, na hipótese de sua não-realização final. Admitir o contrário valeria por despojar-se o instituto das vantagens que determinaram a sua concepção e adoção, como a redução, a um só tempo, da máquina-fiscal e da evasão fiscal a dimensões mínimas, propiciando, portanto, maior comodidade, economia, eficiência e celeridade às atividades de tributação e arrecadação. Ação conhecida apenas em parte e, nessa parte, julgada improcedente". 
cia política". Quanto ao instituto em si da substituição tributária, tenha-se que o Tribunal tem mantido sua chancela a essa técnica fiscal, corolário da responsabilidade tributária, reitera-se: RREE $603.191,{ }^{53} 213.396,{ }^{54}$ $194.382^{55}$ e $266.523 .^{56}$

Além da substituição, no citado capítulo relativo à Responsabilidade Tributária, encontram-se preceitos sobre a responsabilidade dos sucessores (arts. 129 a 133 do CTN), que visam guarnecer os créditos tributários, tornando-os mais objetivos. Tenha-se que a Lei Complementar n. 118/2005 introduziu modificações e

53 BRASIL. Supremo Tribunal Federal. Recurso Extraordinário n. 603.191. Recorrente: Construtora Locatelli Ltda. Recorrida: União Federal (Fazenda Nacional). Relatora: Ministra Ellen Gracie. Local, 1999. Ementa do acórdão: "EMENTA: DIREITO TRIBUTÁRIO. SUBSTITUIÇÃO TRIBUTÁRIA. RETENÇÃO DE 11\% ART. 31 DA LEI 8.212/91, COM A REDAÇÃO DA LEI 9.711/98. CONSTITUCIONALIDADE. 1. Na substituição tributária, sempre teremos duas normas: a) a norma tributária impositiva, que estabelece a relação contributiva entre o contribuinte e o fisco; b) a norma de substituição tributária, que estabelece a relação de colaboração entre outra pessoa e o fisco, atribuindo-lhe o dever de recolher o tributo em lugar do contribuinte. 2. A validade do regime de substituição tributária depende da atenção a certos limites no que diz respeito a cada uma dessas relações jurídicas. Não se pode admitir que a substituição tributária resulte em transgressão às normas de competência tributária e ao princípio da capacidade contributiva, ofendendo os direitos do contribuinte, porquanto o contribuinte não é substituído no seu dever fundamental de pagar tributos. A par disso, há os limites à própria instituição do dever de colaboração que asseguram o terceiro substituto contra o arbítrio do legislador. A colaboração dele exigida deve guardar respeito aos princípios da razoabilidade e da proporcionalidade, não se lhe podendo impor deveres inviáveis, excessivamente onerosos, desnecessários ou ineficazes. 3. Não há qualquer impedimento a que o legislador se valha de presunções para viabilizar a substituição tributária, desde que não lhes atribua caráter absoluto. 4 . A retenção e recolhimento de $11 \%$ sobre o valor da nota fiscal é feita por conta do montante devido, não descaracterizando a contribuição sobre a folha de salários na medida em que a antecipação é em seguida compensada pelo contribuinte com os valores por ele apurados como efetivamente devidos forte na base de cálculo real. Ademais, resta assegurada a restituição de eventuais recolhimentos feitos a maior. 5. Inexistência de extrapolação da base econômica do art. 195, I, a, da Constituição, e de violação ao princípio da capacidade contributiva e à vedação do confisco, estampados nos arts. $145, \$ 1^{\circ}$, e 150 , IV, da Constituição. Prejudicados os argumentos relativos à necessidade de lei complementar, esgrimidos com base no art. 195, $\$ 4^{\circ}$, com a remissão que faz ao art. 154, I, da Constituição, porquanto não se trata de nova contribuição. 6. Recurso extraordinário a que se nega provimento. 7. Aos recursos sobrestados, que aguardavam a análise da matéria por este STF, aplica-se o art. 543-B, § $3^{\circ}$, do CPC”.

54 BRASIL. Supremo Tribunal Federal. Recurso Extraordinário n. 213.396. Recorrente: Estado de São Paulo. Recorrida: Diasa Distribuidora e Importadora de Automóveis S/A. Relator: Ministro Ilmar Galvão. Local, 1997. "TRIBUTÁRIO. ICMS. ESTADO DE SÃO PAULO. COMÉRCIO DE VEÍCULOS NOVOS. ART. 155, \2², XII, B, DA CF/88. CONVÊNIOS ICM Nº 66/88 (ART. 25) E ICMS N N $^{0}$ 107/89. ART. $8^{\circ}$, INC. XIII E $\int 4^{\circ}$, DA LEI PAULISTA N ${ }^{\circ}$ 6.374/89. O regime de substituição tributária, referente ao ICM, já se achava previsto no Decreto-Lei n ${ }^{\circ} 406 / 68$ (art. 128 do CTN e art. $6^{\circ}$, \S $3^{\circ}$ e $4^{\circ}$, do mencionado decreto-lei), normas recebidas pela Carta de 1988, não se podendo falar, nesse ponto, em omissão legislativa capaz de autorizar o exercício, pelos Estados, por meio do Convênio ICM no 66/88, da competência prevista no art. 34, \ $8^{\circ}$, do ADCT/88. Essa circunstância, entretanto, não inviabiliza o instituto que, relativamente a veículos novos, foi instituído pela Lei paulista $\mathrm{n}^{\circ} 6.374 / 89$ (dispositivos indicados) e pelo Convênio ICMS $\mathrm{n}^{\circ}$ $107 / 89$, destinado não a suprir omissão legislativa, mas a atender à exigência prevista no art. $6^{\circ}, \$ 4^{\circ}$, do referido Decreto-Lei n ${ }^{\circ} 406 / 68$, em face da diversidade de estados aos quais o referido regime foi estendido, no que concerne aos mencionados bens. A responsabilidade, como substituto, no caso, foi imposta, por lei, como medida de política fiscal, autorizada pela Constituição, não havendo que se falar em exigência tributária despida de fato gerador. Acórdão que se afastou desse entendimento. Recurso conhecido e provido.”

55 BRASIL. Supremo Tribunal Federal. Recurso Extraordinário n. 194.382. Recorrente: Estado de São Paulo. Recorrida: Divesca Veículos Ltda. Relator: Ministro Maurício Correa. Local, 1995. Ementa do acórdão: "RECURSO EXTRAORDINÁRIO. TRIBUTÁRIO. SUBSTITUIÇÃO TRIBUTÁRIA. IMPRESCINDIBILIDADE DE QUE ESSA HIPÓTESE ESTEJA PREVISTA EM LEI. LEGITIMIDADE DO INSTITUTO JURÍDICO. NÃO-CONHECIMENTO DO RECURSO ESPECIAL. INOCORRÊNCIA DO FENÔMENO DA SUBSTITUIÇÃO DE JULGADO. PREJUDICIALIDADE DO RECURSO EXTRAORDINÁRIO. ALEGAÇÃO IMPROCEDENTE. 1. Não-conhecimento do recurso especial pelo Superior Tribunal de Justiça. Prejudicialidade do recurso extraordinário simultaneamente interposto, tendo em vista o fenômeno processual da substituição de julgado previsto no artigo 512 do Código de Processo Civil. Alegação improcedente. O acórdão somente substituiria a decisão recorrida se o recurso houvesse sido conhecido e provido. 2. É responsável tributário, por substituição, o industrial, o comerciante ou o prestador de serviço, relativamente ao imposto devido pelas anteriores ou subseqüentes saídas de mercadorias ou, ainda, por serviços prestados por qualquer outra categoria de contribuinte. 3. Legitimidade do regime de substituição tributária, dado que a cobrança antecipada do ICMS por meio de estimativa "constitui simples recolhimento cautelar enquanto não há o negócio jurídico de circulação, em que a regra jurídica, quanto ao imposto, incide”. Entendimento doutrinário. Recurso extraordinário conhecido e provido.”

56 BRASIL. Supremo Tribunal Federal. Recurso Extraordinário n. 266.523. Recorrente: Ricar Automóveis Ltda. Recorrido: Estado de Minas Gerais. Relator: Ministro Mauríco Correa. Local, 2000. Ementa do acórdão: “AGRAVO REGIMENTAL EM RECURSO EXTRAORDINÁRIO. TRIBUTÁRIO. SUBSTITUIÇÃO TRIBUTÁRIA. LEGITIMIDADE. BASE DE CÁLCULO PRESUMIDA E VALOR REAL DA OPERAÇÃO. DIFERENÇAS APURADAS. RESTITUIÇÃO. 1. É responsável tributário, por substituição, o industrial, o comerciante ou o prestador de serviço, relativamente ao imposto devido pelas anteriores ou subseqüentes saídas de mercadorias ou, ainda, por serviços prestados por qualquer outra categoria de contribuinte. Legitimidade do regime de substituição tributária declarada pelo Pleno deste Tribunal. 2. Base de cálculo presumida e valor real da operação. Diferenças apuradas. Restituição. Impossibilidade, dada a ressalva contida na parte final do artigo $150, \int 7^{\circ}$, da Constituição Federal, que apenas assegura a imediata e preferencial restituição da quantia paga somente na hipótese em que o fato gerador presumido não se realize. Agravo regimental não provido". 
excepcionou a objetividade do crédito tributário para as situações de falência ou de recuperação judicial.

Nessa toada de proteção ao crédito tributário, no CTN, arts. 134 e 135, estão enunciados preceitos relativos à responsabilidade de terceiros, com especial ênfase para as enunciados preceitos relativos à responsabilidade de terceiros, com especial ênfase para as hipóteses de atos praticados com excesso de poderes ou infração de lei, contrato social ou estatutos. A jurisprudência do Superior Tribunal de Justiça tem sido no sentido de aplicar essa cláusula tributária de modo restritivo, como se viu no julgamento do REsp n. 1.101.728. ${ }^{57}$

No STF, nos autos do RE 562.276, ${ }^{58}$ foi declarada a inconstitucionalidade do art. 13 da Lei n. 8.620/93, na parte em que determinou que os sócios das empresas por cotas de responsabilidade limitada responderiam solidariamente, com seus bens pessoais, pelos débitos junto à Seguridade Social. É de ver, portanto, que, para esses tribunais, o instituto da responsabilização de terceiros deve ser utilizado com extrema cautela pela administração tributária.

57 BRASIL. Superior Tribunal de Justiça. Recurso Especial n. 1.101.728. Recorrente: Borda do Campo Indústria e Comércio Ltda. Recorrido: Estado de São Paulo. Relator: Ministro Teori Zavascki. Local, 2008. Ementa do acórdão: “TRIBUTÁRIO. RECURSO ESPECIAL. EXECUÇÃO FISCAL. TRIBUTO DECLARADO PELO CONTRIBUINTE. CONSTITUIÇÃO DO CRÉDITO TRIBUTÁRIO. PROCEDIMENTO ADMINISTRATIVO. DISPENSA. RESPONSABILIDADE DO SÓCIO. TRIBUTO NÃO PAGO PELA SOCIEDADE. 1. A jurisprudência desta Corte, reafirmada pela Seção inclusive em julgamento pelo regime do art. 543-C do CPC, é no sentido de que 'a apresentação de Declaração de Débitos e Créditos Tributários Federais - DCTF, de Guia de Informação e Apuração do ICMS - GIA, ou de outra declaração dessa natureza, prevista em lei, é modo de constituição do crédito tributário, dispensando, para isso, qualquer outra providência por parte do Fisco’ (REsp 962.379, $1^{\text {a }}$ Seção, DJ de 28.10.08). 2. É igualmente pacífica a jurisprudência do STJ no sentido de que a simples falta de pagamento do tributo não configura, por si só, nem em tese, circunstância que acarreta a responsabilidade subsidiária do sócio, prevista no art. 135 do CTN. É indispensável, para tanto, que tenha agido com excesso de poderes ou infração à lei, ao contrato social ou ao estatuto da empresa (EREsp 374.139/RS, $1^{\text {a }}$ Seção, DJ de 28.02.2005). 3. Recurso especial parcialmente conhecido e, nessa parte, parcialmente provido. Acórdão sujeito ao regime do art. 543-C do CPC e da Resolução STJ 0808”. 58 BRASIL. Supremo Tribunal Federal. Recurso Extraordinário. 562.276. Recorrente: União Federal (Fazenda Nacional). Recorrido: Owner's Bonés Promocionais Ltda - ME. Relatora: Ministra Ellen Gracie. Local, 2007. Ementa do acórdão: "DIREITO TRIBUTÁRIO. RESPONSABILIDADE TRIBUTÁRIA. NORMAS GERAIS DE DIREITO TRIBUTÁRIO. ART 146, III, DA CF. ART. 135, III, DO CTN. SÓCIOS DE SOCIEDADE LIMITADA. ART. 13 DA LEI 8.620/93. INCONSTITUCIONALIDADES FORMAL E MATERIAL. REPERCUSSÃO GERAL. APLICAÇÃO DA DECISÃO PELOS DEMAIS TRIBUNAIS. 1. Todas as espécies tributárias, entre as quais as contribuições de seguridade social, estão sujeitas às normas gerais de direito tributário. 2. O Código Tributário Nacional estabelece algumas regras matrizes de responsabilidade tributária, como a do art. 135, III, bem como diretrizes para que o legislador de cada ente político estabeleça outras regras específicas de responsabilidade tributária relativamente aos tributos da sua competência, conforme seu art. 128. 3. O preceito do art. 124, II, no sentido de que são solidariamente obrigadas 'as pessoas expressamente designadas por lei', não autoriza o legislador a criar novos casos de responsabilidade tributária sem a observância dos requisitos exigidos pelo art. 128 do CTN, tampouco a desconsiderar as regras matrizes de responsabilidade de terceiros estabelecidas em caráter geral pelos arts. 134 e 135 do mesmo diploma. A previsão legal de solidariedade entre devedores - de modo que o pagamento efetuado por um aproveite aos demais, que a interrupção da prescrição, em favor ou contra um dos obrigados, também lhes tenha efeitos comuns e que a isenção ou remissão de crédito exonere a todos os obrigados quando não seja pessoal (art. 125 do CTN) - pressupõe que a própria condição de devedor tenha sido estabelecida validamente. 4. A responsabilidade tributária pressupõe duas normas autônomas: a regra matriz de incidência tributária e a regra matriz de responsabilidade tributária, cada uma com seu pressuposto de fato e seus sujeitos próprios. A referência ao responsável enquanto terceiro (dritter Persone, terzo ou tercero) evidencia que não participa da relação contributiva, mas de uma relação específica de responsabilidade tributária, inconfundível com aquela. O "terceiro" só pode ser chamado responsabilizado na hipótese de descumprimento de deveres próprios de colaboração para com a Administração Tributária, estabelecidos, ainda que a contrario sensu, na regra matriz de responsabilidade tributária, e desde que tenha contribuído para a situação de inadimplemento pelo contribuinte. 5. O art. 135, III, do CTN responsabiliza apenas aqueles que estejam na direção, gerência ou representação da pessoa jurídica e tão-somente quando pratiquem atos com excesso de poder ou infração à lei, contrato social ou estatutos. Desse modo, apenas o sócio com poderes de gestão ou representação da sociedade é que pode ser responsabilizado, o que resguarda a pessoalidade entre o ilícito (má gestão ou representação) e a consequência de ter de responder pelo tributo devido pela sociedade. 6. O art. 13 da Lei 8.620/93 não se limitou a repetir ou detalhar a regra de responsabilidade constante do art. 135 do CTN, tampouco cuidou de uma nova hipótese específica e distinta. Ao vincular à simples condição de sócio a obrigação de responder solidariamente pelos débitos da sociedade limitada perante a Seguridade Social, tratou a mesma situação genérica regulada pelo art. 135, III, do CTN, mas de modo diverso, incorrendo em inconstitucionalidade por violação ao art. 146, III, da CF. 7. O art. 13 da Lei 8.620/93 também se reveste de inconstitucionalidade material, porquanto não é dado ao legislador estabelecer confusão entre os patrimônios das pessoas física e jurídica, o que, além de impor desconsideração ex lege e objetiva da personalidade jurídica, descaracterizando as sociedades limitadas, implica irrazoabilidade e inibe a iniciativa privada, afrontando os arts. $5^{\circ}$, XIII, e 170, parágrafo único, da Constituição. 8. Reconhecida a inconstitucionalidade do art. 13 da Lei 8.620/93 na parte em que determinou que os sócios das empresas por cotas de responsabilidade limitada responderiam solidariamente, com seus bens pessoais, pelos débitos junto à Seguridade Social. 9. Recurso extraordinário da União desprovido. 10. Aos recursos sobrestados, que aguardavam a análise da matéria por este STF, aplica-se o art. 543-B, $₫ 3^{\circ}$, do CPC”. 
Outro tópico que merece atenção consiste na responsabilidade por infração (arts. 136 a 138 do CTN). O Código dispõe que, salvo disposição legal em contrário, “[...] a responsabilidade por infrações da legislação tributária independe da intenção do agente ou do responsável e da efetividade, natureza e extensão dos efeitos do ato". Ou seja, a infração tributária é objetiva. Todavia, o CTN torna a responsabilidade do agente pessoal em algumas situações particulares (art. 137). Cuide-se que, por meio do instituto da "denúncia espontânea" da infração (art. 138, CTN), exclui-se a responsabilidade e as sanções normativas decorrentes do cometimento das infrações.

Trilhando os dispositivos contidos no CTN, alcança-se o Título III que versa sobre o "crédito tributário". Preceitua o Código (arts. 139 a 141) que "[...] o crédito tributário decorre da obrigação principal e tem a mesma natureza desta". Nada obstante, continua o CTN, “[...] as circunstâncias que modificam o crédito tributário, sua extensão ou seus efeitos, ou as garantias ou os privilégios a ele atribuídos, ou que excluem sua exigibilidade, não afetam a obrigação tributária que lhe deu origem".

É um aparente paradoxo. Mas é só uma aparência, pois o que o CTN dispõe que, não obstante seja o crédito tributário uma decorrência da obrigação tributária, com ela não se confunde, tendo a sua autonomia jurídica e o seu próprio regime normativo. ${ }^{59}$ Nessa linha, como já aludido, o direito da Fazenda Pública de exigir o cumprimento da obrigação tributária se dá com o lançamento tributário. Sem lançamento, não há crédito, e, sem crédito, não há direito de cobrar.

O lançamento, regulado entre os artigos 142 a 150 do CTN, é um dos temas mais relevantes do direito tributário. ${ }^{60}$ Segundo o disposto no Código, há três modalidades de lançamento tributário: o de ofício, o por declaração do contribuinte e o por homologação da Fazenda.

No Judiciário brasileiro houve grande disceptação no tocante ao prazo de repetição de indébito tributário em relação aos tributos sujeitos ao lançamento por homologação, resultando em entendimento pacificado na "Tese dos $5+5$ ", como se infere no julgamento do EREsp n. $644.736 .{ }^{61}$ Em face dessa jurisprudência, foi editada a Lei Complementar n. 118/2005, que procurou normatizar essa interpretação.

Sucede que o STF, nos autos do RE n. 566.621, ${ }^{62}$ decretou a inconstitucionalidade da aplicação retroativa

59 SCHOUERI, Luís Eduardo. Direito Tributário. São Paulo: Saraiva, 2011. p. 519-529.

60 BORGES, José Souto Maior. Lançamento tributário. 2. ed. São Paulo: Malheiros, 1999.

61 BRASIL. Superior Tribunal de Justiça. Embargos de Divergência no Recurso Especial n. 644.736. Embargante: União Federal (Fazenda Nacional). Embargado: Caxangá Veículos Ltda. Relator: Ministro Teori Zavascki. Local, 2007. Ementa do acórdão: “CONSTITUCIONAL. TRIBUTÁRIO. REPETIÇÃO DE INDÉBITO. TRIBUTOS SUJEITOS A LANÇAMENTO POR HOMOLOGAÇÃO. PRAZO PRESCRICIONAL. LC 118/2005. INCONSTITUCIONALIDADE DA APLICAÇÃO RETROATIVA. 1. Sobre a prescrição da ação de repetição de indébito tributário de tributos sujeitos a lançamento por homologação, a jurisprudência do STJ (1 ${ }^{\text {a }}$ Seção) assentou o entendimento de que, no regime anterior ao do art. $3^{\circ}$ da LC $118 / 05$, o prazo de cinco anos, previsto no art. 168 do CTN, tem início, não na data do recolhimento do tributo indevido, e sim na data da homologação expressa ou tácita - do lançamento. Assim, não havendo homologação expressa, o prazo para a repetição do indébito acaba sendo de dez anos a contar do fato gerador. 2. A norma do art. $3^{\circ}$ da LC 118/05, que estabelece como termo inicial do prazo prescricional, nesses casos, a data do pagamento indevido, não tem eficácia retroativa. É que a Corte Especial, em sessão de 06/06/2007, DJ 27.08.2007, declarou inconstitucional a expressão 'observado, quanto ao art. $3^{\circ}$, o disposto no art. 106, I, da Lei no 5.172 , de 25 de outubro de 1966 - Código Tributário Nacional', constante do art. 4º segunda parte, da referida Lei Complementar. 3. Embargos de divergência a que se nega provimento".

62 BRASIL. Supremo Tribunal Federal. Recurso Extraordinário n. 566.621. Recorrente: União Federal (Fazenda Nacional). Recorrido: Ruy Cesar Abella Ferreira. Relatora: Ministra Ellen Gracie. Local, 2007. Ementa do acórdão: “DIREITO TRIBUTÁRIO - LEI INTERPRETATIVA - APLICAÇÃO RETROATIVA DA LEI COMPLEMENTAR N 118/2005 - DESCABIMENTO - VIOLAÇÃO À SEGURANÇA JURÍDICA - NECESSIDADE DE OBSERVÂNCIA DA VACACIO LEGIS - APLICAÇÃO DO PRAZO REDUZIDO PARA REPETIÇÃO OU COMPENSAÇÃO DE INDÉBITOS AOS PROCESSOS AJUIZADOS A PARTIR DE 9 DE JUNHO DE 2005. Quando do advento da LC 118/05, estava consolidada a orientação da Primeira Seção do STJ no sentido de que, para os tributos sujeitos a lançamento por homologação, o prazo para repetição ou compensação de indébito era de 10 anos contados do seu fato gerador, tendo em conta a aplicação combinada dos arts. 150, \ $4^{\circ}, 156$, VII, e 168, I, do CTN. A LC 118/05, embora tenha se auto-proclamado interpretativa, implicou inovação normativa, tendo reduzido o prazo de 10 anos contados do fato gerador para 5 anos contados do pagamento indevido. Lei supostamente interpretativa que, em verdade, inova no mundo jurídico deve ser considerada como lei nova. Inocorrência de violação à autonomia e independência dos Poderes, porquanto a lei expressamente interpretativa também se submete, como qualquer outra, ao controle judicial quanto 
contida no art. $4^{\circ}$ da mencionada LC n. 118/2005. Manteve, contudo, incólume o art. $3^{\circ}$, de modo que foi superada a "Tese dos $5+5$ " e o prazo foi reduzido, portanto, de 10 anos contados do fato gerador para cinco anos contados do pagamento indevido.

Após cuidar do lançamento tributário, o CTN disciplina, entre os artigos 151 a 155, as hipóteses de suspensão do crédito tributário. Segundo o Código, suspendem a exigibilidade do crédito: a) a moratória; b) o depósito do seu montante integral; c) as reclamações e os recursos, nos termos da legislação; d) a concessão de liminar ou de tutela antecipada ou em mandado de segurança ou em outras espécies de ação judicial; e) o parcelamento.

O Código continua o tratamento normativo da moratória e do parcelamento. Em relação à moratória, dispõe no parágrafo único do art. 154 que ela não "[...] aproveita aos casos de dolo, fraude ou simulação do sujeito passivo ou do terceiro em benefício daquele". A rigor, esse tipo de preceito normativo deveria ser desnecessário, pois é postulado universal dos direitos e deveres dos povos civilizados que ninguém pode se beneficiar de sua própria torpeza. Mas, neste País, infelizmente, se tudo não estiver bem escrito e bem enunciado, mesmos as "obviedades" se tornam excêntricas, e um ato torpe se torna um ato juridicamente válido e admissível.

Após tratar das hipóteses de suspensão do crédito tributário, o CTN, nos artigos 156 a 174, normatiza as modalidades de extinção do crédito. Segundo o Código, extinguem o crédito tributário: a) o pagamento; b) a compensação; c) a transação; d) a remissão; e) a prescrição; f) a decadência; g) a conversão do depósito em renda; h) o pagamento antecipado e homologado; i) a decisão administrativa irreformável e judicialmente insindicável; j) a decisão judicial passada em julgado; e k) a dação em pagamento em bens imóveis.

O pagamento, para a Fazenda Pública, é o melhor instrumento de extinção do crédito tributário. Mas, uma vez que o devedor fiscal se recusa a pagar a dívida tributária, de melhor e mais simples, ela se transforma na mais complexa de todas as modalidades de extinção do crédito tributário.

O Código regula o dever da Fazenda Pública de repetir (ou devolver) o que foi indevidamente pago aos cofres públicos. Com efeito, nos Estados Democráticos de Direito, que devem se pautar pela "legítima legalidade", o poder deve se contentar em receber o que lhe seja efetivamente devido, nem a mais nem a menos. Os contribuintes devem pagar o estritamente devido. O que for indevidamente pago deve ser devolvido a quem pagou.

Nessa linha, a interpretação a ser dada ao preceito contido no artigo 166 merece cuidadosa atenção. Enuncia o citado dispositivo que:

[...] a restituição de tributos que comportem, por sua natureza, transferência do respectivo encargo financeiro somente será feita a quem prove haver assumido referido encargo, ou, no caso de tê-lo transferido a terceiro, estar por este expressamente autorizado a recebê-la.

O STF editou duas Súmulas tendo esse tema como pano de fundo: a n. 71, de 13.12.1963, e a n. 546, de 3.12.1969. Na Súmula n. 71, está enunciado que “[...] embora pago indevidamente, não cabe restituição de tributo indireto", e na Súmula n. 546, que "[...] cabe a restituição do tributo pago indevidamente, quando reconhecido

à sua natureza, validade e aplicação. A aplicação retroativa de novo e reduzido prazo para a repetição ou compensação de indébito tributário estipulado por lei nova, fulminando, de imediato, pretensões deduzidas tempestivamente à luz do prazo então aplicável, bem como a aplicação imediata às pretensões pendentes de ajuizamento quando da publicação da lei, sem resguardo de nenhuma regra de transição, implicam ofensa ao princípio da segurança jurídica em seus conteúdos de proteção da confiança e de garantia do acesso à Justiça. Afastando-se as aplicações inconstitucionais e resguardando-se, no mais, a eficácia da norma, permite-se a aplicação do prazo reduzido relativamente às ações ajuizadas após a vacatio legis, conforme entendimento consolidado por esta Corte no enunciado 445 da Súmula do Tribunal. O prazo de vacatio legis de 120 dias permitiu aos contribuintes não apenas que tomassem ciência do novo prazo, mas também que ajuizassem as ações necessárias à tutela dos seus direitos. Inaplicabilidade do art. 2.028 do Código Civil, pois, não havendo lacuna na LC 118/08, que pretendeu a aplicação do novo prazo na maior extensão possível, descabida sua aplicação por analogia. Além disso, não se trata de lei geral, tampouco impede iniciativa legislativa em contrário. Reconhecida a inconstitucionalidade art. $4^{\circ}$, segunda parte, da LC 118/05, considerando-se válida a aplicação do novo prazo de 5 anos tão-somente às ações ajuizadas após o decurso da vacatio legis de 120 dias, ou seja, a partir de 9 de junho de 2005. Aplicação do art. 543-B, \ $3^{\circ}$, do CPC aos recursos sobrestados. Recurso extraordinário desprovido". 
por decisão, que o contribuinte de 'de jure' não recuperou do contribuinte 'de facto' o 'quantum' respectivo'.

Nada obstante as intenções do legislador, chanceladas pela Suprema Corte, é de rigor que o Estado não deve se apropriar indevidamente do que não lhe seja de direito. Assim, entendo que aquele que recolheu tributo indevido tem o direito a sua repetição. Insiste-se que o Estado Democrático de Direito é o "poder legal e legítimo". É ilegítimo que o Estado se aproprie de valores indevidos.

Dentro dessa "legítima legalidade", o CTN regula os institutos da prescrição e da decadência tributárias. A rigor, ocorrido o fato gerador da obrigação tributária nasce, em princípio, o dever do sujeito passivo de pagar o tributo. O direito da Fazenda de exigir esse pagamento somente ocorre com a constituição, via lançamento, do crédito tributário. É uma situação aparentemente paradoxal. Se a ocorrência do fato gerador da obrigação tributária implica o dever do sujeito passivo, em princípio, como a outra "face dessa moeda" deveria surgir o direito da Fazenda. Mas, não é essa a sistemática do Código. O direito da Fazenda surge com o crédito. O crédito surge com o lançamento, e não com o fato gerador da obrigação tributária.

Pois bem, um dos postulados éticos supremos dos sistemas jurídicos dos povos civilizados consiste na segurança ou na paz. ${ }^{63} \mathrm{O}$ tempo é um fator de estabilização, de segurança e de paz. As situações jurídicas devem ocorrer dentro de determinados marcos temporais. Esse aspecto ético do Direito foi bem capturado pelo ministro Cezar Peluso, nos autos do RE n. 363.889, ${ }^{64}$ que cuidou dos temas coisa julgada e ação de investigação de paternidade, ocasião em que Sua Excelência afirma que "[...] ninguém consegue viver dignamente sem certeza jurídica".

Como viver em um mundo incerto, inseguro e sem paz é muito perigoso, cuidou o CTN de estabelecer os prazos para que a Fazenda constituísse o seu crédito e, uma vez constituído, pudesse cobrá-lo (arts. 173 e 174). Assim, conforme preceitua o Código, o prazo decadencial de constituição do crédito se dá em cinco anos. E o prazo prescricional para a sua cobrança também se expira em cinco anos. Por esse mesmo postulado de segurança jurídica, o contribuinte também dispõe de prazos para exigir da Fazenda a devolução do indevidamente pago, conforme já aludimos.

E, antes de se alcançar o capítulo específico das garantias e privilégios do crédito tributário, passa-se pelo Capítulo V que versa sobre a exclusão do crédito tributário (arts. 175 a 182). Segundo o CTN, excluem o crédito tributário: a isenção e a anistia.

Ainda viceja no solo jurídico brasileiro um forte debate acerca das similitudes e das diferenças entre os institutos tributários da isenção e da imunidade. Cuide-se que esse debate não é só acadêmico, pois há manifestações do STF que a partir da distinção entre isenção e imunidade ensejam consequências normativas

63 ÁVILA, Humberto. Seguranca jurídica: entre permanência, mudança e realização no direito tributário. São Paulo: Malheiros, 2011.

64 BRASIL. Supremo Tribunal Federal. Recurso Extraordinário n. 363.889. Recorrentes: Ministério Público do Distrito Federal e Territórios e outro. Recorrido: Goiá Fonseca Rates. Relator: Ministro Dias Toffoli. Local, 2002. Ementa do acórdão: "EMENTA RECURSO EXTRAORDINÁRIO. DIREITO PROCESSUAL CIVIL E CONSTITUCIONAL. REPERCUSSÃO GERAL RECONHECIDA. AÇÃO DE INVESTIGAÇÃO DE PATERNIDADE DECLARADA EXTINTA, COM FUNDAMENTO EM COISA JULGADA, EM RAZÃO DA EXISTÊNCIA DE ANTERIOR DEMANDA EM QUE NÃO FOI POSSÍVEL A REALIZAÇÃO DE EXAME DE DNA, POR SER O AUTOR BENEFICÁRIO DA JUSTIÇA GRATUITA E POR NÃO TER O ESTADO PROVIDENCIADO A SUA REALIZAÇÃO. REPROPOSITURA DA AÇÃ̃O. POSSIBILIDADE, EM RESPEITO À PREVALÊNCIA DO DIREITO FUNDAMENTAL À BUSCA DA IDENTIDADE GENÉTICA DO SER, COMO EMANAÇÃO DE SEU DIREITO DE PERSONALIDADE. 1. É dotada de repercussão geral a matéria atinente à possibilidade da repropositura de ação de investigação de paternidade, quando anterior demanda idêntica, entre as mesmas partes, foi julgada improcedente, por falta de provas, em razão da parte interessada não dispor de condições econômicas para realizar o exame de DNA e o Estado não ter custeado a produção dessa prova. 2. Deve ser relativizada a coisa julgada estabelecida em ações de investigação de paternidade em que não foi possível determinar-se a efetiva existência de vínculo genético a unir as partes, em decorrência da não realização do exame de DNA, meio de prova que pode fornecer segurança quase absoluta quanto à existência de tal vínculo. 3. Não devem ser impostos óbices de natureza processual ao exercício do direito fundamental à busca da identidade genética, como natural emanação do direito de personalidade de um ser, de forma a tornar-se igualmente efetivo o direito à igualdade entre os filhos, inclusive de qualificações, bem assim o princípio da paternidade responsável. 4. Hipótese em que não há disputa de paternidade de cunho biológico, em confronto com outra, de cunho afetivo. Busca-se o reconhecimento de paternidade com relação a pessoa identificada. 5. Recursos extraordinários conhecidos e providos". 
distintas, como sucedeu no julgamento do direito de creditamento IPI nas hipóteses de insumos imunes ou isentos ou sujeitos à alíquota zero: RREE $212.484,{ }^{65} 357.277,{ }^{66} 353.657,{ }^{67} 370.682^{68}$ e $566.819 .{ }^{69}$

Pois bem, nada obstante essas distinções normativas, na linha do magistério doutrinário de Sacha Calmon, ${ }^{70} \mathrm{a}$ isenção é a exoneração legalmente qualificada, enquanto que a imunidade é a exoneração constitucionalmente qualificada, ou seja, a diferença entre a imunidade e a isenção encontra-se no veículo normativo: a isenção é veiculada pela lei e a imunidade pela Constituição.

Em reforço a essa perspectiva, colhe-se o disposto no art. 150, $₫ 6^{\circ}, \mathrm{CF}$, preceituando que :

[...] qualquer subsídio ou isenção, redução de base de cálculo, concessão de crédito presumido, anistia ou remissão, relativos a impostos, taxas e contribuições, só poderá ser concedido mediante lei específica, federal, estadual ou municipal, que regule exclusivamente as matérias acima enumeradas ou o correspondente tributo ou contribuição, sem prejuízo do disposto no art. 155, \ $2^{\circ}$, XII, g.

É de ver, portanto, que se cuida de uma garantia constitucional ao crédito tributário. Nada obstante, tenha-se que para o contribuinte o que efetivamente importa é se ele deve pagar e quanto ele deve pagar de tributo. Se houver norma exonerando do dever de pagar ou diminuindo o quanto se deve pagar, para o contribuinte pouco importa o veículo normativo ou o nome do instituto exonerativo, se imunidade, não incidência, isenção, redução de base de cálculo, redução de alíquota, alíquota zero etc.

Essa especial proteção do crédito tributário decorre de alguns hábitos equivocados de política fiscal no Brasil. Não são raras as políticas fiscais que manipulam os tributos com finalidades extrafiscais, com indesejáveis consequências, como sucede, por exemplo, com as "guerras fiscais" entre Estados ou entre Municípios.

Não se está a infirmar a possibilidade de o Estado usar os tributos com finalidades extrafiscais, pois em

65 BRASIL. Supremo Tribunal Federal. Recurso Extraordinário n. 212.484. Redatoria Ministro Nelson Jobim. Recorrente: União Federal (Fazenda Nacional). Recorrida: Vonpar Refrescos S/A, 1997. Ementa do acórdão: "CONSTITUCIONAL. TRIBUTÁRIO. IPI. ISENÇÃO INCIDENTE SOBRE INSUMOS. DIREITO DE CRÉDITO. PRINCÍPIO DA NÃO CUMULATIVIDADE. OFENSA NÃO CARACTERIZADA. Não ocorre ofensa à CF (art. 153, $\int 3^{\circ}$, II) quando o contribuinte do IPI credita-se do valor do tributo incidente sobre insumos adquiridos sob o regime de isenção. Recurso não conhecido".

66 BRASIL. Supremo Tribunal Federal. Recurso Extraordinário n. 357.277. Redatoria Ministro Nelson Jobim. Recorrente: União Federal (Fazenda Nacional). Recorrida: Cooperativa Vinícola Garibaldi. Local, 2002. Ementa do acórdão: "CONSTITUCIONAL. TRIBUTÁRIO. IPI. CREDITAMENTO. INSUMOS ISENTOS, SUJEITOS À ALÍQUOTA ZERO. Se o contribuinte do IPI pode creditar o valor dos insumos adquiridos sob o regime de isenção, inexiste razão para deixar de reconhecer-lhe o mesmo direito na aquisição de insumos favorecidos pela alíquota zero, pois nada extrema, na prática, as referidas figuras desonerativas, notadamente quando se trata de aplicar o princípio da não-cumulatividade. A isenção e a alíquota zero em um dos elos da cadeia produtiva desapareceriam quando da operação subseqüente, se não admitido o crédito. Recurso não conhecido".

67 BRASIL. Supremo Tribunal Federal. Recurso Extraordinário n. 353.657. Recorrente: União Federal (Fazenda Nacional). Recorrida: Madeireira Santo Antônio Ltda. Relator: Ministro Marco Aurélio. Local, 2002. Ementa do acórdão: "IPI - INSUMO - ALÍQUOTA ZERO - AUSÊNCIA DE DIREITO AO CREDITAMENTO. Conforme disposto no inciso II do $\ 3^{\circ}$ do artigo 153 da Constituição Federal, observa-se o princípio da não-cumulatividade compensando-se o que for devido em cada operação com o montante cobrado nas anteriores, ante o que não se pode cogitar de direito a crédito quando o insumo entra na indústria considerada a alíquota zero. IPI -INSUMO - ALÍQUOTA ZERO - CREDITAMENTO - INEXISTÊNCIA DO DIREITO - EFICÁCIA. Descabe, em face do texto constitucional regedor do Imposto sobre Produtos Industrializados e do sistema jurisdicional brasileiro, a modulação de efeitos do pronunciamento do Supremo, com isso sendo emprestada à Carta da República a maior eficácia possível, consagrando-se o princípio da segurança jurídica".

68 BRASIL. Supremo Tribunal Federal. Recurso Extraordinário n. 370.682. Recorrente: União Federal (Fazenda Nacional). Recorrida: Indústria de Embalagens Plásticas Guará Ltda. Relator: Ministro Ilmar Galvão. Local, 2003. Ementa do acórdão: “Recurso extraordinário. Tributário. 2. IPI. Crédito Presumido. Insumos sujeitos à alíquota zero ou não tributados. Inexistência. 3. Os princípios da não-cumulatividade e da seletividade não ensejam direito de crédito presumido de IPI para o contribuinte adquirente de insumos não tributados ou sujeitos à alíquota zero. 4. Recurso extraordinário provido".

69 BRASIL. Supremo Tribunal Federal. Recurso Extraordinário n. 566.819. Recorrente: Jofran Embalagens Ltda. Recorrida: União Federal (Fazenda Nacional). Relator: Ministro Marco Aurélio. Local, 2007. Ementa do acórdão: "IPI - CRÉDITO. A regra constitucional direciona ao crédito do valor cobrado na operação anterior. IPI - CRÉDITO - INSUMO ISENTO. Em decorrência do sistema tributário constitucional, o instituto da isenção não gera, por si só, direito a crédito. IPI - CRÉDITO - DIFERENÇA - INSUMO - ALÍQUOTA. A prática de alíquota menor - para alguns, passível de ser rotulada como isenção parcial - não gera o direito a diferença de crédito, considerada a do produto final”.

70 COELHO, Sacha Calmon Navarro. Curso de direito tributário brasileiro. 8. ed. Rio de Janeiro: Forense, 2005, p. 876. 
algumas situações isso se faz necessário, como ocorre, por exemplo, com a forte oneração de fumígeros ou de bebidas alcoólicas, cuja principal finalidade é pedagógica, visando desestimular o consumo desses produtos nocivos e insidiosos à saúde das pessoas.

Mas o que se tem acompanhado é uma política tributária voltada, não raras vezes, para atender a outras finalidades, com a utilização de instrumentos fiscais como se fossem instrumentos de incentivo econômico. Esse uso equivocado do direito tributário é nocivo à coletividade. E tais práticas normativas problemáticas normalmente se transformam em questões judiciais.

Mas essas questões judiciais problemáticas se tornam dramáticas quando o contribuinte confia na legislação estadual ou municipal e essa legislação é posteriormente declarada inconstitucional, devendo o contribuinte pagar valores que julgava não devidos. ${ }^{71}$ Para essas situações excepcionais o sistema jurídico tem o instituto normativo da modulação dos efeitos.

Tanto a doutrina quanto a jurisprudência brasileira agasalham o dogma da nulidade da lei declarada inconstitucional. Assim, ela não pode ter produzido efeitos válidos e a decisão judicial que decreta a sua inconstitucionalidade tem caráter "declaratório" e com efeitos retroativos.

Sem embargo da vetustez desse dogma e da respeitabilidade de seus defensores, entendo que a tese kelseniana da anulabilidade da lei inconstitucional, em vista do caráter constitutivo do reconhecimento da inconstitucionalidade - a decisão e dos efeitos prospectivos - é mais coerente com a vida real. ${ }^{72}$ Com efeito, sob a égide da Constituição de 1988, e tendo em perspectiva o julgamento da Ação Direta de Inconstitucionalidade n. $2{ }^{73}$ restou pacificado no seio da jurisprudência brasileira o entendimento segundo o qual a lei inconstitucional é nula ab initio.

Todavia, em situações excepcionais, o STF admite a possibilidade de afastar esse dogma da nulidade com a concessão de efeitos prospectivos, acolhendo a tese da anulabilidade, com esteio nos artigos 27 e 11, das respectivas Leis n. 9.868/99 e n. 9.882/99, que autorizam o Tribunal, por aprovação de 2/3 dos Ministros, tendo em vista razões de segurança jurídica e/ou de excepcional interesse social, modular os efeitos das decisões de inconstitucionalidade no controle concentrado de constitucionalidade.

No controle difuso, o Tribunal também tem precedentes no sentido da manipulação dos efeitos das decisões nos feitos de controle difuso de constitucionalidade, como ocorreu no julgamento do RE n. 197.917. ${ }^{74}$

71 ANDRADE, Fábio Martins de. Modulação em matéria tributária: o argumento pragmático ou consequencialista de cunho econômico e as decisões do STF. São Paulo: Quartier Latin, 2011.

72 KELSEN, Hans. Jurisdição constitucional. 3. ed. São Paulo: Martins Fontes, 2013.

73 BRASIL. Supremo Tribunal Federal. Ação Direta de Inconstitucionalidade n. 2. Requerente: Federação Nacional dos Estabelecimentos de Ensino - FENEN. Requerido: Presidente da República. Relator: Ministro Paulo Brossard. Local, 1988. Ementa do acórdão: “CONSTITUIÇÃO. LEI ANTERIOR QUE A CONTRARIE. REVOGAÇÃO. INCONSTITUCIONALIDADE SUPERVENIENTE. IMPOSSIBILIDADE. 1. A lei ou é constitucional ou não é lei. Lei inconstitucional é uma contradição em si. A lei é constitucional quando fiel à Constituição; inconstitucional na medida em que a desrespeita, dispondo sobre o que lhe era vedado. $\mathrm{O}$ vício da inconstitucionalidade é congênito à lei e há de ser apurado em face da Constituição vigente ao tempo de sua elaboração. Lei anterior não pode ser inconstitucional em relação à Constituição superveniente; nem o legislador poderia infringir Constituição futura. A Constituição sobrevinda não torna inconstitucionais leis anteriores com ela conflitantes: revoga-as. Pelo fato de ser superior, a Constituição não deixa de produzir efeitos revogatórios. Seria ilógico que a lei fundamental, por ser suprema, não revogasse, ao ser promulgada, leis ordinárias. A lei maior valeria menos que a lei ordinária. 2. Reafirmação da antiga jurisprudência do STF, mais que cinqüentenária. 3. Ação direta de que se não conhece por impossibilidade jurídica do pedido".

74 BRASIL. Supremo Tribunal Federal. Recurso Extraordinário n. 197.917. Recorrente: Ministério Público do Estado de São Paulo. Recorrida: Câmara Municipal de Mira Estrela. Relator: Ministro Maurício Corrêa. Local, 1987. Ementa do acórdão: "RECURSO EXTRAORDINÁRIO. MUNICÍPIOS. CÂMARA DE VEREADORES. COMPOSIÇÃO. AUTONOMIA MUNICIPAL. LIMITES CONSTITUCIONAIS. NÚMERO DE VEREADORES PROPORCIONAL À POPULAÇÃO. CF, ARTIGO 29, IV. APLICAÇÃO DE CRITÉRIO ARITMÉTICO RÍGIDO. INVOCAÇÃO DOS PRINCÍPIOS DA ISONOMIA E DA RAZOABILIDADE. INCOMPATIBILIDADE ENTRE A POPULAÇÃO E O NÚMERO DE VEREADORES. INCONSTITUCIONALIDADE, INCIDENTER TANTUM, DA NORMA MUNICIPAL. EFEITOS PARA O FUTURO. SITUAÇÃO EXCEPCIONAL. 1. O artigo 29, inciso IV da Constituição Federal, exige que o número de Vereadores seja proporcional à população dos Municípios, observados os limites mínimos e máximos fixados pelas alíneas a, b e c. 2. Deixar a critério do legislador municipal o estabelecimento da composição das Câmaras Municipais, com observância apenas dos limites máximos e mínimos do preceito (CF, artigo 29) é tornar sem sentido a previsão constitucional expressa da proporcionalidade. 3. Situação real e 
No recente julgamento do RE n. 586.453, ${ }^{75}$ a Corte decidiu que a exigência para modular os efeitos de decisão em matéria constitucional necessita da aprovação de $2 / 3$ dos membros, nos mesmos moldes do que ocorre com o controle concentrado e abstrato de constitucionalidade. O Tribunal, por questão de coerência normativa, aproximou o modelo processual do recurso extraordinário com repercussão geral do modelo processual do controle concentrado de constitucionalidade.

Mas eis uma situação peculiar do sistema jurídico brasileiro. Nos termos do art. 97 da Constituição Federal, "[...] somente pelo voto da maioria absoluta de seus membros ou dos membros do respectivo órgão especial poderão os tribunais declarar a inconstitucionalidade de lei ou ato normativo do Poder Público". Assim, no caso do STF, somente seis votos podem declarar uma norma inconstitucional, mas para modular os efeitos da decisão são necessários oito votos.

Ora, o que é mais importante? Declarar a inconstitucionalidade ou modular os efeitos das decisões? À luz da dinâmica jurisprudencial do STF, modular os efeitos é mais importante do que declarar a inconstitucionalidade de uma norma. A rigor, deveria ser o contrário: para declarar uma norma inconstitucional, deveria ser exigido o voto de oito ministros ou 2/3 dos membros de um Tribunal ou de seu órgão especial, enquanto que a modulação poderia ser feita pelo quorum da maioria simples. ${ }^{76}$

A modulação dos efeitos de uma decisão judicial não passa de um ato de política judiciária, pautada pela conveniência e pela oportunidade. Insiste-se, o grave não é a modulação de efeitos, mas a declaração de inconstitucionalidade. Por que a defesa da anulabilidade das leis e a modulação de seus efeitos? Porque no mundo real, entre o início de um processo legislativo e o fim de um processo judicial dista longo prazo.

No mundo real, das situações concretas da vida, as leis vigem até decisão judicial ou legislativa em contrário. Assim, enquanto não houver decisão judicial suspendendo a validade e a eficácia de uma lei, essa lei deve continuar vigendo e produzindo efeitos jurídicos. Passados vários anos, uma decisão judicial, ainda que seja do STF, declarando a inconstitucionalidade de uma lei não pode desprezar todo o período de vigência normativa dessa lei. Isso provocaria incerteza, insegurança, instabilidade, enfim, provocaria o caos. E o direito é ordem. A razão de ser do sistema jurídico é impor a ordem sobre o caos. De modo que, decisão judicial provocadora de caos é uma não decisão. Direito é paz com justiça.

contemporânea em que Municípios menos populosos têm mais Vereadores do que outros com um número de habitantes várias vezes maior. Casos em que a falta de um parâmetro matemático rígido que delimite a ação dos legislativos Municipais implica evidente afronta ao postulado da isonomia. 4. Princípio da razoabilidade. Restrição legislativa. A aprovação de norma municipal que estabelece a composição da Câmara de Vereadores sem observância da relação cogente de proporção com a respectiva população configura excesso do poder de legislar, não encontrando eco no sistema constitucional vigente. 5. Parâmetro aritmético que atende ao comando expresso na Constituição Federal, sem que a proporcionalidade reclamada traduza qualquer afronta aos demais princípios constitucionais e nem resulte formas estranhas e distantes da realidade dos Municípios brasileiros. Atendimento aos postulados da moralidade, impessoalidade e economicidade dos atos administrativos (CF, artigo 37). 6. Fronteiras da autonomia municipal impostas pela própria Carta da República, que admite a proporcionalidade da representação política em face do número de habitantes. Orientação que se confirma e se reitera segundo o modelo de composição da Câmara dos Deputados e das Assembleias Legislativas (CF, artigos 27 e 45, \ $1^{\circ}$ ). 7. Inconstitucionalidade, incidenter tantun, da lei local que fixou em 11 (onze) o número de Vereadores, dado que sua população de pouco mais de 2600 habitantes somente comporta 09 representantes. 8. Efeitos. Princípio da segurança jurídica. Situação excepcional em que a declaração de nulidade, com seus normais efeitos ex tunc, resultaria grave ameaça a todo o sistema legislativo vigente. Prevalência do interesse público para assegurar, em caráter de exceção, efeitos pro futuro à declaração incidental de inconstitucionalidade. Recurso extraordinário conhecido e em parte provido".

75 BRASIL. Supremo Tribunal Federal. Recurso Extraordinário n. 586.453. Recorrente: Fundação Petrobrás de Seguridade Social - PETROS. Recorrida: Petróleo Brasileiro S/A - PETROBRAS. Relatora: Ministra Rosa Weber. Local, 2008. Extrato da decisão: "O Tribunal resolveu questão de ordem no sentido da exigência de quorum de 2/3 para modular os efeitos da decisão em sede de recurso extraordinário com repercussão geral, vencidos os Ministros Dias Toffoli, Luiz Fux, Gilmar Mendes e Celso de Mello, que entendiam haver a necessidade de maioria absoluta. Participaram da votação na questão de ordem os Ministros Teori Zavascki e Rosa Weber. Em seguida, o Tribunal modulou os efeitos da decisão para reconhecer a competência da justiça trabalhista para processar e julgar, até o trânsito em julgado (20.2.2013)".

76 A Comissão de Constituição e Justiça da Câmara dos Deputados aprovou a admissibilidade da PEC - Proposta de Emenda à Constituição n. 33/11 que "Altera a quantidade mínima de votos de membros de tribunais para declaração de inconstitucionalidade de leis; condiciona o efeito vinculante de súmulas aprovadas pelo Supremo Tribunal Federal à aprovação pelo Poder Legislativo e submete ao Congresso Nacional a decisão sobre a inconstitucionalidade de Emendas à Constituição". Disponível em: <www. camara.gov.br>. Acesso em: 
Retorna-se ao crédito tributário. Chega-se nas suas garantias e privilégios.

\section{As GARANTIAS, OS PRIVILÉGIOS E AS PREFERÊNCIAS DO CRÉDITO TRIBUTÁRIO}

O Código Tributário Nacional (arts. 183 a 193, Capítulo VI), coerentemente, preceitua que “[...] as garantias atribuídas neste Capítulo ao crédito tributário não exclui outras que sejam expressamente previstas em lei, em função da natureza ou das características do tributo a que se refiram”. É de ver, portanto, que, no plano dos textos legislativos, o crédito tributário goza de especial proteção, e todo reforço em favor do fortalecimento do crédito tributário é justificado por sua posição sobranceira.

No art. 184, CTN, tem dispositivo de grande proteção ao crédito tributário, na medida em que somente os bens e as rendas que a lei declare absolutamente impenhoráveis estarão fora do alcance da responsabilidade tributária. Isso significa que somente lei federal pode indicar quais bens e rendas estão fora da garantia do crédito tributário. Somente a lei pode indicar o que não será alcançado pela responsabilização tributária.

Nada obstante o rol de bens impenhoráveis no art. 649 do Código de Processo Civil, é de se interpretar o art. 184, CTN, em sentido mais robusto, pois a execução do crédito tributário é especial e, na dúvida entre a aplicação de uma lei geral ou de uma lei específica, prevalece a específica. A jurisprudência contrária ao crédito tributário é excepcional, como ocorre na hipótese de proteção ao bem de família, nos termos da Lei n. 8.009/1990, desde que não sejam de tributos ou contribuições decorrentes do próprio imóvel.

Todavia, o STF, apreciando questões tributárias envolvendo os Correios, tem decidido que a ECT - Empresa Brasileira de Correios e Telégrafos - não pode ter os próprios bens penhoráveis para o pagamento de dívidas, sejam fiscais, trabalhistas ou de qualquer natureza, por força do disposto no art. 12 do Decreto-lei n. 509/1969, excepcionando a regra disposta no art. 173, \ 2 ${ }^{\circ}$, CF, como se vê nos autos dos RREE n.220.906 $6^{77}$ e n. $601.392 .^{78}$

77 BRASIL. Supremo Tribunal Federal. Recurso Extraordinário n. 220.906. Recorrente: ECT - Empresa Brasileira de Correios e Telégrafos. Recorrido: Ismar José da Costa. Relator: Ministro Maurício Corrêa. Local, 1997. Ementa do acórdão: 'RECURSO EXTRAORDINÁRIO. CONSTITUCIONAL. EMPRESA BRASILEIRA DE CORREIOS E TELÉGRAFOS. IMPENHORABILIDADE DE SEUS BENS, RENDAS E SERVIÇOS. RECEPÇÃO DO ARTIGO 12 DO DECRETO-LEI Nº 509/69. EXECUÇÃO. OBSERVÂNCIA DO REGIME DE PRECATÓRIO. APLICAÇÃO DO ARTIGO 100 DA CONSTITUIÇÃO FEDERAL. 1. À empresa Brasileira de Correios e Telégrafos, pessoa jurídica equiparada à Fazenda Pública, é aplicável o privilégio da impenhorabilidade de seus bens, rendas e serviços. Recepção do artigo 12 do Decreto-lei no 509/69 e não-incidência da restrição contida no artigo $173, \int 1^{\circ}$, da Constituição Federal, que submete a empresa pública, a sociedade de economia mista e outras entidades que explorem atividade econômica ao regime próprio das empresas privadas, inclusive quanto às obrigações trabalhistas e tributárias. 2. Empresa pública que não exerce atividade econômica e presta serviço público da competência da União Federal e por ela mantido. Execução. Observância ao regime de precatório, sob pena de vulneração do disposto no artigo 100 da Constituição Federal. Recurso extraordinário conhecido e provido".

78 BRASIL. Supremo Tribunal Federal. Recurso Extraordinário n. 601.392. Redatoria Ministro Gilmar Mendes. Recorrente: ECT - Empresa Brasileira de Correios e Telégrafos. Recorrido: Município de Curitiba. Relator: Ministro Gilmar Mendes. Local, 2009. Extrato da decisão: “Os serviços prestados pela Empresa Brasileira de Correios e Telégrafos - ECT estão abrangidos pela imunidade recíproca (CF, art. 150, VI, a, e $\iint 2^{\circ}$ e $3^{\circ}$ ). Essa a orientação do Plenário que, ao concluir julgamento, por maioria, proveu recurso extraordinário interposto de acórdão em que se limitara o colimado benefício aos serviços tipicamente postais mencionados no art. $9^{\circ}$ da Lei 6.538/78. A Corte de origem entendera lícito ao município recorrido a cobrança de Imposto sobre Serviços - ISS relativamente àqueles não abarcados pelo monopólio concedido pela União — v. Informativos 628 e 648. Na sessão de 16.11.2011, o Min. Ayres Britto registrou, de início, que a manutenção do correio aéreo nacional e dos serviços postais e telegráficos pela recorrente não poderia sofrer solução de continuidade, de maneira a ser obrigatoriamente sustentada pelo Poder Público, ainda que lhe gerasse prejuízo. Além do mais, reputou possível a adoção de política tarifária de subsídios cruzados, porquanto os Correios realizariam também direitos fundamentais da pessoa humana — comunicação telegráfica e telefônica e o sigilo dessas comunicações -, em atendimento que alçaria todos os municípios brasileiros (integração nacional) com tarifas módicas. Assinalou que, na situação dos autos, a extensão do regime de imunidade tributária seria natural, haja vista que a recorrente seria longa manus da União, em exercício de atividade absolutamente necessária e mais importante do que a própria compostura jurídica ou a estrutura jurídico-formal da empresa. O Min. Gilmar Mendes, em reforço ao que referido, ressaltou que a base do monopólio da ECT estaria sofrendo esvaziamento, tornando-se ultrapassada, diante da evolução tecnológica. Ressurtiu que a recorrente, mesmo quando exercesse atividades fora do regime de privilégio, sujeitar-se-ia a condições decorrentes desse status, não extensíveis à iniciativa privada, a exemplo da exigência de prévia licitação e da realização de concurso público. Concluiu que, enquanto não houvesse a mudança preconizada na ADPF 46/DF (DJe de 26.2.2010), a imunidade 
O STF, no caso da ECT, tem entendido que a empresa tem, para efeitos de dívidas fiscais e trabalhistas, o mesmo regime jurídico das pessoas jurídicas de direito público; mas, no recente julgamento do RE n. $589.998,{ }^{79}$ que cuidava da eventual estabilidade do servidor público, preconizada no art. 41, CF, o Tribunal entendeu inaplicável aos empregados da ECT.

Nos citados leading cases que reconheceram esse regime jurídico de direito público da ECT, o Tribunal, enfrentando uma penhora dos bens da ECT, decorrente do cumprimento de decisão judicial em execução trabalhista, criou a figura do "precatório informal" e da "interpretação constitucional com base no próprio Supremo".

O "precatório informal” foi o que disse o ministro Nelson Jobim. Sua Excelência (fl. 479, RE n. 220.096) afirma que a ECT recebe um ofício do TRT e faz um lançamento. Ou seja, sem nenhuma base normativa, a ECT paga suas dívidas com espeque em um "precatório informal". À míngua dessa base normativa, o ministro Ilmar Galvão indagou se esse entendimento é firmado no "direito natural”, pois não há respaldo no "direito positivo brasileiro". O ministro Moreira Alves rebate dizendo que não é por direito natural, mas com base em interpretação do Supremo Tribunal Federal (fls. 479-483).

Mas, indaga-se: a interpretação do STF tem base normativa constitucional? Não. O parâmetro do Tribunal foi ele mesmo, pois o sistema normativo vigente (art. 100, CF) não autorizava o Tribunal a decidir que a ECT pagasse os seus débitos via precatórios informais. Nenhum tribunal pode decidir as causas com base em si próprio. Há de existir um parâmetro normativo válido e vigente, sob pena de se cair no arbítrio e no despotismo judicial. Toda decisão judicial, seja de que grau for, deve estar em conformidade com o ordenamento jurídico, deve estar em sintonia com o Direito e com a Justiça.

Juiz ou tribunal que decide com base em si mesmo, lembra o barão de Munchausen. Esse folclórico e ilustre personagem narrava uma estória segundo a qual ele e seu cavalo caíram em um lago. Estavam afundando, mas o barão teve a ideia de se puxar pelos próprios cabelos, e retirou a si e a seu cavalo apenas com a força de seu braço soerguendo-se, pelas próprias tranças do cabelo, sem nenhum ponto de apoio externo. ${ }^{80}$

Foi o que fez o Tribunal no citado exemplo. Em rigor, todas as vezes que um juiz ou tribunal decide sem amparo no ordenamento jurídico, ele faz às vezes de barão de Munchausen. Esse tipo de comportamento judicial enfraquece a confiança no sistema jurídico, e a quebra de confiança no Direito é ruim para a credibilidade das instituições. Crédito é credibilidade.

O CTN, no art. 185, enuncia que “[...] presume-se fraudulenta a alienação ou oneração de bens ou rendas, ou o seu começo, por sujeito passivo em débito para com a Fazenda Pública, por crédito tributário regularmente inscrito como dívida ativa". Essa presunção é afastada se o sujeito passivo reservar valores suficientes para garantir o pagamento de seus débitos devidamente inscritos (art. 185, parágrafo único).

A Lei Complementar n. 118/2005 acrescentou ao CTN o artigo 185-A que dispôs de reforço processual à proteção do crédito ao permitir que, mediante ordem judicial, sejam postos em indisponibilidade os bens e os direitos patrimoniais do devedor, inclusive com o bloqueio eletrônico de ativos financeiros. Essas medidas constritivas são draconianas, mas ou a proteção ao crédito tributário é forte e é para valer, ou não há que se falar em garantia do crédito. Cuide-se que, nos termos do art. 204, CTN, a dívida regularmente inscrita goza de presunção de certeza e liquidez e tem efeito de prova pré-constituída, podendo, todavia, ser ilidida

recíproca aplicar-se-ia em relação ao ISS, sob pena de desorganização desse serviço, dado que os municípios o tributariam de modo distinto. RE 601392/PR, rel. orig. Min. Joaquim Barbosa, red. p/ o acórdão Min. Gilmar Mendes, 28.2.2013. (Informativo STF n. 696, 1. 3.2013)”.

79 BRASIL. Supremo Tribunal Federal. Recurso Extraordinário n. 589.998. Recorrente: ECT - Empresa Brasileira de Correios e Telégrafos. Recorrido: Humberto Pereira Rodrigues. Relator: Ministro Ricardo Lewandowski. Local, 2008. Extrato da decisão: “O Tribunal deu provimento parcial ao recurso extraordinário para reconhecer a inaplicabilidade do art. 41 da Constituição Federal e exigir-se a necessidade de motivação para a prática legítima do ato de rescisão unilateral do contrato de trabalho, vencidos parcialmente os Ministros Eros Grau e Marco Aurélio. O Relator reajustou parcialmente seu voto. Em seguida, o Tribunal rejeitou questão de ordem do advogado da Empresa Brasileira de Correios e Telégrafos - ECT que suscitava fossem modulados os efeitos da decisão. Plenário, 20.03.2013 (Informativo STF n. 699)".

80 RASPE, Rudolf Erich. As aventuras do barão de Munchausen. Trad. Ana Goldberger. São Paulo: Iluminuras, 2013. p. 66. 
mediante prova inequívoca a cargo do sujeito passivo ou de terceiro interessado.

No título do visitado Capítulo VI, constam os termos "garantias" e "privilégios", mas o Código, a partir do art. 186, dispõe sobre "preferências". Segundo o CTN, o crédito tributário prefere a quaisquer outros créditos, exceto os decorrentes da legislação trabalhista ou de acidente de trabalho, bem como na hipótese de falência, em relação aos créditos extraconcursais.

A jurisprudência do STJ tem admitido que os créditos alimentares tenham preferência sobre os créditos tributários, mas dúvidas pairam em relação aos honorários advocatícios.

Inicialmente, o Tribunal entendeu que os créditos de honorários advocatícios seriam alimentares e teriam preferência sobre os créditos tributários (REsp 608.028). ${ }^{81}$ Posteriormente (e atualmente), essa orientação se modificou e, segundo o STJ, os créditos tributários preferem aos honorários advocatícios (EResp n. 1.146.066) ${ }^{82}$

Nada obstante o entendimento segundo o qual os créditos alimentares preferem aos créditos tributários, é possível entender que essa preferência decorre em relação àqueles oriundos de sentenças judiciais ou de pensões alimentícias, diretamente envolvidos na controvérsia judicial. Sendo assim, não é equivocado o entendimento do STJ no sentido de que os créditos tributários preferem aos honorários advocatícios.

Tema que interessa à Federação é concernente ao concurso de preferências disposto no parágrafo único do art. 187 do CTN. Segundo o Código, o crédito da União prefere em relação aos créditos dos Estados e Municípios; os dos Estados preferem aos dos Municípios. O STF tem a Súmula n. 563, de 15.12.1976: “[...] o concurso de preferência a que se refere o art. 187 do Código Tributário Nacional é compatível com o disposto no art. $9^{\circ}$, I, da Constituição Federal".

É defensável a tese, segundo a qual, em face da Constituição de 1988, esse preceito deve ser interpretado de outra maneira, pois não há hierarquia normativa entre a União, os Estados e os Municípios, uma vez que existente, isso sim, uma repartição constitucional de competências políticas e administrativas. ${ }^{83}$

O Código disciplina outras preferências do crédito tributário, como a que determina o pagamento preferencial dos créditos vencidos ou vincendos em face de créditos habilitados em inventários, arrolamentos ou processos de liquidação judicial (arts. 189 e 190).

O CTN, no art. 191, preceitua que "[...] a extinção das obrigações do falido requer prova de quitação de todos os tributos”. E no art. 191-A, “[...] a concessão de recuperação judicial depende da apresentação da prova de quitação de todos os tributos". Determina o Código, no art. 192, que “[...] nenhuma sentença de julgamento de partilha ou de adjudicação será proferida sem prova de quitação de todos os tributos relativos aos bens do espólio, ou às suas rendas”.

E, como último dispositivo do citado Capítulo VI, tem-se o disposto no art. 193:

81 BRASIL. Superior Tribunal de Justiça. Recurso Especial n. 608.028. Recorrentes: Alfredo Cândido Santos Ferreira e outro. Recorridos: Caninha Camponesa Centro Oeste Distribuidora de Bebidas Ltda e outra. Relatora: Ministra Nancy Andrighi. Local, 2005. Ementa: "Civil. Recurso especial. Ação de execução. Concurso de credores. Crédito tributário. Crédito de honorários advocatícios. Natureza alimentar. Ordem de preferência. Os honorários advocatícios, mesmo de sucumbência, têm natureza alimentar. A aleatoriedade no recebimento dessas verbas não retira tal característica, da mesma forma que, no âmbito do Direito do Trabalho, a aleatoriedade no recebimento de comissões não retira sua natureza salarial. A ausência de subordinação é irrelevante. Subordinação é um dos elementos de uma relação de emprego, mas não é o elemento específico que justifica a natureza alimentar do salário. O que a justifica é a necessidade de o empregado recebê-lo para viabilizar sua sobrevivência, aspecto que também se encontra no trabalho não subordinado prestado pelo causídico. Sendo alimentar a natureza dos honorários, estes preferem aos créditos tributários em execução contra devedor solvente. Inteligência do art. 186 do CTN”. Recurso especial a que se dá provimento.

82 BRASIL. Superior Tribunal de Justiça. Embargos de Divergência em Recurso Especial. Embargante: Claudionor Siqueira Benite. Embargada: Fazenda Nacional. Relator: Ministro Francisco Falcão. Local, 2010. Ementa: “CRÉDITOS DECORRENTES DE HONORÁRIOS ADVOCATÍCIOS. PRIVILÉGIO EM RELAÇÃO AOS CRÉDITOS TRIBUTÁRIOS. INEXISTÊNCIA. ARTIGOS 24 DA LEI 8.90694 e 186 DO CTN. I - Não obstante possua natureza alimentar e detenha privilégio geral em concurso de credores, o crédito decorrente de honorários advocatícios não precede ao crédito tributário, que sequer se sujeita a concurso de credores e prefere a qualquer outro, seja qual for o tempo de sua constituição ou a sua natureza (artigos 24 da Lei 8.90694 e 186 do CTN). II - Embargos de divergência improvidos".

83 CARVALHO, Paulo de Barros. Curso de direito tributário. 22. ed. São Paulo: Saraiva, 2010. p. 649-650. 
[...] salvo quando expressamente autorizado por lei, nenhum departamento da administração pública da União, dos Estados, do Distrito Federal ou dos Municípios, ou sua autarquia, celebrará contrato ou aceitará proposta em concorrência pública sem que contratante ou proponente faça prova da quitação de todos os tributos devidos à Fazenda Pública interessada, relativos à atividade em cujo exercício contrata ou concorre.

Esses são os preceitos normativos contidos no CTN sobre as garantias, privilégios e preferências do crédito tributário, sem embargo da existência de outras normas de reforço do crédito. Mas, como enuncia o próprio CTN, essas garantias, privilégios e preferências não se esgotam no específico capítulo nem mesmo no próprio Código.

Convém tecer breves considerações a respeito da Administração Tributária e o poder dever de fiscalização do Estado (arts. 194 a 208). O Tribunal enfrentará novamente a questão da quebra do sigilo bancário ou financeiro diretamente pelas autoridades administrativas, nos autos do RE n. $601.314 .{ }^{84}$ Diz-se novamente porque a Corte, nos autos do RE n. 389.808, ${ }^{85}$ decidiu que, sem ordem judicial, não pode a administração tributária quebrar o sigilo bancário dos contribuintes.

Essa decisão foi um duro golpe na fiscalização tributária e poderá ocasionar imensos prejuízos à recuperação

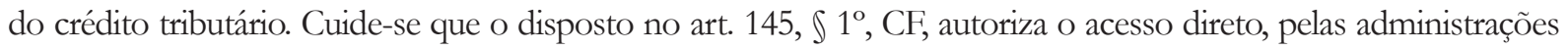
tributárias, dos dados financeiros e bancários dos contribuintes, sem necessidade de uma ordem judicial, bastando, tão somente, o devido processo administrativo, que já é bastante rigoroso nessas hipóteses de sigilo bancário e sigilo fiscal. Além do citado preceito, o art. 37, incisos XVIII e XXII, CF, dá suporte normativo à preponderância do Fisco e a uma integração das administrações fazendárias, visando, insista-se, ao fortalecimento do crédito tributário.

\section{A Constituição Federal é uma Constituição Tributária.}

Outro tema sensível para as administrações fazendárias consiste na jurisprudência do STF em relação às sanções políticas. Com efeito, o Tribunal tem uma tendência jurisprudencial segundo a qual os eventuais ônus administrativos que venham a constranger o devedor fiscal são sanções políticas. Essa linha interpretativa da Corte tem de ser vista com bastante cautela, pois o eventual afrouxamento da fiscalização e de ônus administrativos pode ensejar a práticas reiteradas de descumprimento da legislação tributária.

Ora, esse nocivo hábito tem afetado, inclusive, a concorrência e a competitividade entre os agentes econômicos, pois, insista-se, o não cumprimento das obrigações fiscais de alguns criará desequilíbrios com os que cumprem os seus deveres. O Tribunal tem várias manifestações sobre esse tema das sanções políticas:

84 BRASIL, Supremo Tribunal Federal. Recurso Extraordinário n. 601.314. Recorrente: Márcio Holcman. Recorrida: União Federal (Fazenda Nacional). Relator: Ministro Ricardo Lewandowski. Local, 2009: "EMENTA: CONSTITUCIONAL. SIGILO BANCÁRIO. FORNECIMENTO DE INFORMAÇÕES SOBRE MOVIMENTAÇÃO BANCÁRIA DE CONTRIBUINTES, PELAS INSTITUIÇÕES FINANCEIRAS, DIRETAMENTE AO FISCO, SEM PRÉVIA AUTORIZAÇÃO JUDICIAL (LEI COMPLEMENTAR 105/2001). POSSIBILIDADE DE APLICAÇÃO DA LEI 10.174/2001 PARA APURAÇÃO DE CRÉDITOS TRIBUTÁRIOS REFERENTES A EXERCÍCIOS ANTERIORES AO DE SUA VIGÊNCIA. RELEVÂNCIA JURÍDICA DA QUESTÃO CONSTITUCIONAL. EXISTÊNCIA DE REPERCUSSÃO GERAL”.

85 BRASIL. Supremo Tribunal Federal. Recurso Extraordinário n. 389.808. Recorrente: G.V.A. Indústria e Comércio S/A. Recorrida: União Federal (Fazenda Nacional). Relator: Ministro Marco Aurélio. Local, 2003. "EMENTA: SIGILO DE DADOS - AFASTAMENTO. Conforme disposto no inciso XII do artigo $5^{\circ}$ da Constituição Federal, a regra é a privacidade quanto à correspondência, às comunicações telegráficas, aos dados e às comunicações, ficando a exceção - a quebra do sigilo - submetida ao crivo de órgão equidistante - o Judiciário - e, mesmo assim, para efeito de investigação criminal ou instrução processual penal. SIGILO DE DADOS BANCÁRIOS - RECEITA FEDERAL. Conflita com a Carta da República norma legal atribuindo à Receita Federal - parte na relação jurídico-tributária - o afastamento do sigilo de dados relativos ao contribuinte". 
Súmulas n. $70,{ }^{86}$ n. $323^{87}$ e n. $547,{ }^{88}$ ADI n. $173,{ }^{89}$ AC n. $1.657,{ }^{90}$ ADI n. $395^{91}$ e RE n. $413.782,{ }^{92}$ dentre outros.

86 BRASIL. Supremo Tribunal Federal. Súmula n. 70, Local, de 13 de dezembro de 1963. "[...] é inadmissível a interdição de estabelecimento como meio coercitivo para cobrança de tributo".

87 BRASIL. Supremo Tribunal Federal. Súmula n. 323. Local, de 13 de dezembro de 1963. [...] é inadmissível a apreensão de mercadorias como meio coercitivo para pagamento de tributos".

88 BRASIL. Supremo Tribunal Federal. Súmula n. 547. Local, de 3 de dezembro de 1969. "[...] não é lícito à autoridade proibir que o contribuinte em débito adquira estampilhas, despache mercadorias nas alfândegas e exerça suas atividades profissionais".

89 BRASIL, Supremo Tribunal Federal. Ação Direta de Inconstitucionalidade n. 173. Requerente: Confederação Nacional da Indústria. Requeridos: Presidente da República e Congresso Nacional. Relator: Ministro Joaquim Barbosa. Local, 1990. Ementa: "CONSTITUCIONAL. DIREITO FUNDAMENTAL DE ACESSO AO JUDICIÁRIO. DIREITO DE PETIÇÃO. TRIBUTÁRIO E POLÍTICA FISCAL. REGULARIDADE FISCAL. NORMAS QUE CONDICIONAM A PRÁTICA DE ATOS DA VIDA CIVIL E EMPRESARIAL À QUITAÇÃO DE CRÉDITOS TRIBUTÁRIOS. CARACTERIZAÇÃO ESPECÍFICA COMO SANÇÃO POLÍTICA. AÇÃO CONHECIDA QUANTO À LEI FEDERAL 7.711/1988, ART. 1º I, III E IV, PAR. $1^{\circ}$ A $3^{\circ}$, E ART. $2^{\circ}$. 1. Ações diretas de inconstitucionalidade ajuizadas contra os arts. $1^{\circ}$, I, II, III e IV, par. $1^{\circ}$ a $3^{\circ}$ e $2^{\circ}$ da Lei 7.711/1988, que vinculam a transferência de domicilio para o exterior (art. $1^{\circ}$, I), registro ou arquivamento de contrato social, alteração contratual e distrato social perante o registro público competente, exceto quando praticado por microempresa (art. $1^{\circ}$, III), registro de contrato ou outros documentos em Cartórios de Registro de Títulos e Documentos (art. $1^{\circ}, \mathrm{IV}$, a), registro em Cartório de Registro de Imóveis (art. $1^{\circ}, \mathrm{IV}, \mathrm{b}$ ) e operação de empréstimo e de financiamento junto a instituição financeira, exceto quando destinada a saldar dívidas para com as Fazendas Nacional, Estaduais ou Municipais (art. $1^{\circ}, \mathrm{IV}, \mathrm{c}$ ) - estas três últimas nas hipóteses de o valor da operação ser igual ou superior a cinco mil Obrigações do Tesouro Nacional - à quitação de créditos tributários exigíveis, que tenham por objeto tributos e penalidades pecuniárias, bem como contribuições federais e outras imposições pecuniárias compulsórias. 2. Alegada violação do direito fundamental ao livre acesso ao Poder Judiciário (art. $5^{\circ}, \mathrm{XXXV}$ da Constituição), na medida em que as normas impedem o contribuinte de ir a juízo discutir a validade do crédito tributário. Caracterização de sanções políticas, isto é, de normas enviesadas a constranger o contribuinte, por vias oblíquas, ao recolhimento do crédito tributário. 3. Esta Corte tem historicamente confirmado e garantido a proibição constitucional às sanções políticas, invocando, para tanto, o direito ao exercício de atividades econômicas e profissionais lícitas (art. 170, par. ún., da Constituição), a violação do devido processo legal substantivo (falta de proporcionalidade e razoabilidade de medidas gravosas que se predispõem a substituir os mecanismos de cobrança de créditos tributários) e a violação do devido processo legal manifestado no direito de acesso aos órgãos do Executivo ou do Judiciário tanto para controle da validade dos créditos tributários, cuja inadimplência pretensamente justifica a nefasta penalidade, quanto para controle do próprio ato que culmina na restrição. É inequívoco, contudo, que a orientação firmada pelo Supremo Tribunal Federal não serve de escusa ao deliberado e temerário desrespeito à legislação tributária. Não há que se falar em sanção política se as restrições à prática de atividade econômica objetivam combater estruturas empresariais que têm na inadimplência tributária sistemática e consciente sua maior vantagem concorrencial. Para ser tida como inconstitucional, a restrição ao exercício de atividade econômica deve ser desproporcional e não-razoável. 4. Os incisos I, III e IV do art. $1^{\circ}$ violam o art. $5^{\circ}$, XXXV da Constituição, na medida em que ignoram sumariamente o direito do contribuinte de rever em âmbito judicial ou administrativo a validade de créditos tributários. Violam, também o art. 170, par. ún. da Constituição, que garante o exercício de atividades profissionais ou econômicas lícitas. Declaração de inconstitucionalidade do art. 1º, I, III e IV da Lei 7.711/'988. Declaração de inconstitucionalidade, por arrastamento dos parágrafos $1^{\circ}$ a $3^{\circ}$ e do art. $2^{\circ}$ do mesmo texto legal". "CONSTITUCIONAL. TRIBUTÁRIO. SANÇÃO POLÍTICA. PROVA DA QUITAÇÃO DE CRÉDITOS TRIBUTÁRIOS NO ÂMBITO DE PROCESSO LICITATÓRIO. REVOGAÇ̃̃O DO ART. 1ª II DA LEI 7.711/1988 PELA LEI 8.666/1993. EXPLICITAÇÃO DO ALCANCE DO DISPOSITIVO. AÇÃO DIRETA DE INCONSTITUCIONALIDADE NÃO CONHECIDA QUANTO AO PONTO. 5. Ação direta de inconstitucionalidade não conhecida, em relação ao art. 1º II da Lei 7.711/1988, na medida em que revogado, por estar abrangido pelo dispositivo da Lei 8.666/1993 que trata da regularidade fiscal no âmbito de processo licitatório. 6. Explicitação da Corte, no sentido de que a regularidade fiscal aludida implica 'exigibilidade da quitação quando o tributo não seja objeto de discussão judicial' ou 'administrativa'. Ações Diretas de Inconstitucionalidade parcialmente conhecidas e, na parte conhecida, julgadas procedentes.” 90 BRASIL, Supremo Tribunal Federal. Ação Cautelar n. 1.657. Requerente: American Virginia Indústria e Comércio, Importação e Exportação de Tabacos Ltda. Requerida: União Federal (Fazenda Nacional). Relator: Ministro Joaquim Barbosa. Local, 2007. Ementa: "RECURSO. Extraordinário. Efeito suspensivo. Inadmissibilidade. Estabelecimento industrial. Interdição pela Secretaria da Receita Federal. Fabricação de cigarros. Cancelamento do registro especial para produção. Legalidade aparente. Inadimplemento sistemático e isolado da obrigação de pagar Imposto sobre Produtos Industrializados - IPI. Comportamento ofensivo à livre concorrência. Singularidade do mercado e do caso. Liminar indeferida em ação cautelar. Inexistência de razoabilidade jurídica da pretensão. Votos vencidos. Carece de razoabilidade jurídica, para efeito de emprestar efeito suspensivo a recurso extraordinário, a pretensão de indústria de cigarros que, deixando sistemática e isoladamente de recolher o Imposto sobre Produtos Industrializados, com conseqüente redução do preço de venda da mercadoria e ofensa à livre concorrência, viu cancelado o registro especial e interditados os estabelecimentos".

91 BRASIL, Supremo Tribunal Federal. Ação Direta de Inconstitucionalidade n. 395. Requerente: Conselho Federal da Ordem dos Advogados do Brasil. Requerida: Assembleia Legislativa do Estado de São Paulo. Relatora: Ministra Cármen Lúcia. Local, 1990. Ementa: "AÇÃ̃O DIRETA DE INCONSTITUCIONALIDADE. ART. 163, \ $7^{\circ}$, DA CONSTITUIÇÃO DE SÃO PAULO: INOCORRÊNCIA DE SANÇÕES POLÍTICAS. AUSÊNCIA DE AFRONTA AO ART. 5, INC. XIII, DA CONSTITUIÇÃO DA REPÚBLICA. 1.

A retenção da mercadoria, até a comprovação da posse legítima daquele que a transporta, não constitui coação imposta em desrespeito ao princípio do devido processo legal tributário. 2. Ao garantir o livre exercício de qualquer trabalho, ofício ou profissão, o art. $5^{\circ}$, inc. XIII, da Constituição da República não o faz de forma absoluta, pelo que a observância dos recolhimentos tributários no desempenho dessas atividades impõe-se legal e legitimamente. 3. A hipótese de retenção temporária de mercadorias prevista no art. 163, \ $7^{\circ}$, da Constituição de São Paulo, é providência para a fiscalização do cumprimento da legislação tributária nesse território e consubstancia exercício do poder de polícia da Administração Pública Fazendária, estabelecida legalmente para os casos de ilícito tributário. Inexiste, por isso mesmo, a alegada coação indireta do contribuinte para satisfazer débitos com a Fazenda Pública. 4. Ação Direta de Inconstitucionalidade julgada improcedente". 92 BRASIL. Supremo Tribunal Federal. Recurso Extraordinário n. 413.782. Recorrente: VARIG S/A. Recorrido: Estado de Santa Catarina. Relator: Ministro Marco Aurélio. Local, 2004. Ementa: “DÉBITO FISCAL - IMPRESSÃO DE NOTAS FISCAIS - PROIBIÇÃO 
Em linha de princípio é de se entender que a vedação às sanções políticas tributárias deve ocorrer na hipótese de ato ou procedimento estatal for manifestamente desarrazoado e desproporcional, colocando em risco a atividade empresarial ou econômica lícita do contribuinte.

Nessa perspectiva, após a visitação à estática normativa (textos), à dinâmica normativa (decisões judiciais) e à doutrina jurídica (magistério acadêmico), vê-se que o crédito tributário, apesar de todos os esforços da administração tributária, ainda está longe de ser plenamente eficaz. Com efeito, os agentes fiscais, neste País, estão longe de conquistarem o indispensável respeito para que as leis tributárias sejam obedecidas ou temidas. ${ }^{93} 94$

\section{Considerações finais}

As leis não têm pernas, nem braços, nem bocas. É preciso que alguém corra, pegue ou fale por elas. Mas de nada adiantam muitos braços, pernas e bocas se os destinatários das leis não quiserem voluntariamente aderir a elas. Não há braços, pernas e bocas suficientes para garantirem o fiel cumprimento de todas as leis. A livre adesão e a obediência às leis, especialmente as lícitas e as legítimas, é o melhor caminho para a estabilidade social.

O crédito tributário, nos regimes políticos democráticos, consiste na legítima e lícita pretensão da Fazenda Pública em cobrar os valores que lhe sejam devidos pelos contribuintes ou responsáveis. Nos sistemas legítimos, ninguém tem o direito jurídico ou moral de não cumprir com as suas obrigações sociais e jurídicas.

A despeito de uma legislação protetiva do crédito tributário, os juízes e os tribunais brasileiros tendem a decidir no sentido de restringirem os poderes e as faculdades da fiscalização da administração tributária, ampliando substantivamente as prerrogativas dos contribuintes ou responsáveis devedores.

Essa orientação jurisprudencial deve ser influência de um passado autoritário dos governos brasileiros, de modo que, contra a sanha arrecadatória dos Fiscos, faz-se necessário opor freios. Todavia, nos regimes democráticos, tanto os Fiscos quanto os contribuintes devem pautar suas condutas em rigorosa obediência ao Direito e à Justiça. Se acaso, o Fisco ou o contribuinte se desviarem dos caminhos da legalidade, deve o Judiciário corrigir esses desvios, de modo a garantir a higidez e a idoneidade do crédito tributário.

\section{REFERÊNCIAS}

ANDRADE, Fábio Martins de. Modulação em matéria tributária: o argumento pragmático on consequencialista de cunho econômico e as decisões do STF. São Paulo: Quartier Latin, 2011.

- INSUBSISTÊNCIA. Surge conflitante com a Carta da República legislação estadual que proíbe a impressão de notas fiscais em bloco, subordinando o contribuinte, quando este se encontra em débito para com o fisco, ao requerimento de expedição, negócio a negócio, de nota fiscal avulsa".

93 SUASSUNA, Ariano. O Auto da Compadecida. 11. ed. Rio de Janeiro: Agir, 1975.

94 ARRAES, Guel; FALCÃO, Adriana; FALCÃO, João. O Auto da Compadecida: adaptação da obra de Ariano Suassuna. Rio de Janeiro: Rede Globo, 1999. Recorde-se outra peça shakespeariana, mas da autoria de Ariano Suassuna intitulada o "Auto da Compadecida", na sua adaptação para o cinema/televisão, que também tem uma "cláusula penal” similar à contida em "O Mercador de Veneza". Mas nesse caso, outra passagem desse clássico da arte brasileira. Cuida-se da ordem do cangaceiro "capitão" Severino de Aracaju para que um "cabra" seu atire no padre e no bispo. O jagunço diz que não gosta de matar padre não, que dá um azar danado, mas que "capitão" mandou, está mandado. E atira matando os sacerdotes católicos. É o que muitas vezes ocorre com os procuradores fiscais. Nem sempre gostam de fazer o que fazem: cobrar tributos. Mas se a "capitã” Lei mandou está mandado. Não tem alternativa a não ser cobrar os tributos legalmente devidos. De preferência, sem ter de cortar uma libra de carne ou uma "tira de couro". E sem ter de derramar uma gota de sangue. 
ANDRADE, José Maria Arruda de. Interpretação da norma tributária. São Paulo: MP, 2006.

ARRAES, Guel; FALCÃO, Adriana; FALCÃO, João. O Auto da Compadecida: adaptação da obra de Ariano Suassuna. Rio de Janeiro: Rede Globo, 1999.

ATALIBA, Geraldo. Hipótese de incidência tributária. 5. ed. São Paulo: Malheiros, 1992.

ÁVILA, Humberto. Segurança jurídica: entre permanência, mudança e realização no direito tributário. São Paulo: Malheiros, 2011.

BALEEIRO, Aliomar. Direito tributário brasileiro. 11. ed. Atualizado por Misabel Derzi. Rio de Janeiro: Forense, 2005.

BALEEIRO, Aliomar. Limitações constitucionais ao poder de limitar. 7. ed. Atualizada por Misabel Abreu Machado Derzi. Rio de Janeiro: Forense, 2005.

BECKER, Alfredo Augusto. Teoria geral do direito tributário. 3. ed. São Paulo: Lejus, 1998.

BÍBLIA Sagrada. Novo Testamento. Mateus, capítulo 21, versículo 31; Lucas, capítulo 19, versículos 1-9.

BOBBIO, Norberto. O futuro da democracia. Tradução de Marco Aurélio Nogueira. São Paulo: Paz e Terra, 2000 .

BORGES, José Souto Maior. Lançamento tributário. 2. ed. São Paulo: Malheiros, 1999.

BRASIL. Instituto de Pesquisa Econômica e Aplicada. Custo e tempo do processo de execução fiscal promovido pela Procuradoria Geral da Fazenda Nacional (PGFN). Comunicados do IPEA, Brasília, n. 127, 2012. Disponível em: <www.ipea.gov.br>. Acesso em:

BRASIL. Lei n. 5.172, de 25.10.1966. Código Tributário Nacional, Capítulo VI - Garantias e Privilégios do Crédito Tributário, arts. 183 a 193. Local: Editora, ano.

BRASIL. Superior Tribunal de Justiça. Embargos de Divergência em Recurso Especial. Embargante: Claudionor Siqueira Benite. Embargada: Fazenda Nacional. Relator: Ministro Francisco Falcão. Local, 2010.

BRASIL. Superior Tribunal de Justiça. Embargos de Divergência no Recurso Especial n. 644.736. Embargante: União Federal (Fazenda Nacional). Embargado: Caxangá Veículos Ltda. Relator: Ministro Teori Zavascki. Local, 2007.

BRASIL. Superior Tribunal de Justiça. Recurso Especial n. 1.101.728. Recorrente: Borda do Campo Indústria e Comércio Ltda. Recorrido: Estado de São Paulo. Relator: Ministro Teori Zavascki. Local, 2008.

BRASIL. Superior Tribunal de Justiça. Recurso Especial n. 608.028. Recorrentes: Alfredo Cândido Santos Ferreira e outro. Recorridos: Caninha Camponesa Centro Oeste Distribuidora de Bebidas Ltda e outra. Relatora: Ministra Nancy Andrighi. Local, 2005.

BRASIL. Supremo Tribunal Federal. Ação Cautelar n. 1.657. Requerente: American Virginia Indústria e Comércio, Importação e Exportação de Tabacos Ltda. Requerida: União Federal (Fazenda Nacional). Relator: Ministro Joaquim Barbosa. Local, 2007.

BRASIL. Supremo Tribunal Federal. Ação Direta de Inconstitucionalidade n. 173. Requerente: Confederação Nacional da Indústria. Requeridos: Presidente da República e Congresso Nacional. Relator: Ministro Joaquim Barbosa. Local, 1990.

BRASIL. Supremo Tribunal Federal. Ação Direta de Inconstitucionalidade n. 395. Requerente: Conselho Federal da Ordem dos Advogados do Brasil. Requerida: Assembleia Legislativa do Estado de São Paulo. Relatora: Ministra Cármen Lúcia. Local, 1990.

BRASIL. Supremo Tribunal Federal. Ação direta de inconstitucionalidade n. 2.446. Requerente: Confederação Nacional da Indústria. Requeridos: Presidente da República e Congresso Nacional. Relatora originária: Mi- 
nistra Ellen Gracie. Relatora redistribuída: Ministra Cármen Lúcia. Local, 2001.

BRASIL. Supremo Tribunal Federal. Ação direta de inconstitucionalidade n. 2.675. Requerente: Governador do Estado de Pernambuco. Requerida: Assembléia Legislativa do Estado de Pernambuco. Relator originário: Ministro Carlos Velloso. Relator: redistribuído: Ministro Ricardo Lewandowski. Local, 2002.

BRASIL. Supremo Tribunal Federal. Ação direta de inconstitucionalidade n. 2.777. Relatoria originária Ministro Sydney Sanches. Relatoria redistribuída Ministro Teori Zavascki. Requerente: Governador do Estado de São Paulo. Requerida: Assembleia Legislativa do Estado de São Paulo. Local, 2002.

BRASIL. Supremo Tribunal Federal. Ação direta de inconstitucionalidade n. 1.851. Requerente: Confederação Nacional do Comércio. Requerido: Estado de Alagoas. Relator: Ministro Ilmar Galvão. Local, 1998.

BRASIL. Supremo Tribunal Federal. Ação Direta de Inconstitucionalidade n. 2. Requerente: Federação Nacional dos Estabelecimentos de Ensino - FENEN. Requerido: Presidente da República. Relator: Ministro Paulo Brossard. Local, 1988.

BRASIL. Supremo Tribunal Federal. Recurso Extraordinário n. 194.382. Recorrente: Estado de São Paulo. Recorrida: Divesca Veículos Ltda. Relator: Ministro Maurício Correa. Local, 1995.

BRASIL. Supremo Tribunal Federal. Recurso Extraordinário n. 197.917. Recorrente: Ministério Público do Estado de São Paulo. Recorrida: Câmara Municipal de Mira Estrela. Relator: Ministro Maurício Corrêa. Local, 1987.

BRASIL. Supremo Tribunal Federal. Recurso Extraordinário n. 212.484. Redator: Ministro Nelson Jobim. Recorrente: União Federal (Fazenda Nacional). Recorrida: Vonpar Refrescos S/A. Local, 1997.

BRASIL. Supremo Tribunal Federal. Recurso Extraordinário n. 213.396. Recorrente: Estado de São Paulo. Recorrida: Diasa Distribuidora e Importadora de Automóveis S/A. Relator: Ministro Ilmar Galvão. Local, 1997.

BRASIL. Supremo Tribunal Federal. Recurso Extraordinário n. 220.906. Recorrente: ECT - Empresa Brasileira de Correios e Telégrafos. Recorrido: Ismar José da Costa. Relator: Ministro Maurício Corrêa. Local, 1997.

BRASIL. Supremo Tribunal Federal. Recurso Extraordinário n. 266.523. Recorrente: Ricar Automóveis Ltda. Recorrido: Estado de Minas Gerais. Relator: Ministro Mauríco Correa. Local, 2000.

BRASIL. Supremo Tribunal Federal. Recurso Extraordinário n. 353.657. Recorrente: União Federal (Fazenda Nacional). Recorrida: Madeireira Santo Antônio Ltda. Relator: Ministro Marco Aurélio. Local, 2002.

BRASIL. Supremo Tribunal Federal. Recurso Extraordinário n. 357.277. Redatoria Ministro Nelson Jobim. Recorrente: União Federal (Fazenda Nacional). Recorrida: Cooperativa Vinícola Garibaldi. Local, 2002.

BRASIL. Supremo Tribunal Federal. Recurso Extraordinário n. 363.889. Recorrentes: Ministério Público do Distrito Federal e Territórios e outro. Recorrido: Goiá Fonseca Rates. Relator: Ministro Dias Toffoli. Local, 2002.

BRASIL. Supremo Tribunal Federal. Recurso Extraordinário n. 370.682. Recorrente: União Federal (Fazenda Nacional). Recorrida: Indústria de Embalagens Plásticas Guará Ltda. Relator: Ministro Ilmar Galvão. Local, 2003.

BRASIL. Supremo Tribunal Federal. Recurso Extraordinário n. 389.808. Recorrente: G.V.A. Indústria e Comércio S/A. Recorrida: União Federal (Fazenda Nacional). Relator: Ministro Marco Aurélio. Local, 2003.

BRASIL. Supremo Tribunal Federal. Recurso Extraordinário n. 413.782. Recorrente: VARIG S/A. Recorrido: Estado de Santa Catarina. Relator: Ministro Marco Aurélio. Local, 2004.

BRASIL. Supremo Tribunal Federal. Recurso Extraordinário n. 566.621. Recorrente: União Federal (Fazenda Nacional). Recorrido: Ruy Cesar Abella Ferreira. Relatora: Ministra Ellen Gracie. Local, 2007. 
BRASIL. Supremo Tribunal Federal. Recurso Extraordinário n. 566.819. Recorrente: Jofran Embalagens Ltda. Recorrida: União Federal (Fazenda Nacional). Relator: Ministro Marco Aurélio. Local, 2007.

BRASIL. Supremo Tribunal Federal. Recurso Extraordinário n. 586.453. Recorrente: Fundação Petrobrás de Seguridade Social - PETROS. Recorrida: Petróleo Brasileiro S/A - PETROBRAS. Relatora: Ministra Rosa Weber. Local, 2008.

BRASIL. Supremo Tribunal Federal. Recurso Extraordinário n. 589.998. Recorrente: ECT - Empresa Brasileira de Correios e Telégrafos. Recorrido: Humberto Pereira Rodrigues. Relator: Ministro Ricardo Lewandowski. Local, 2008.

BRASIL. Supremo Tribunal Federal. Recurso Extraordinário n. 593.849. Recorrente: Parati Petróleo Ltda. Recorrido: Estado de Minas Gerais. Relator: Ministro Ricardo Lewandowski. Local, 2008.

BRASIL. Supremo Tribunal Federal. Recurso Extraordinário n. 596.832. Recorrentes: Posto de Gasolina Rei de Mesquita Ltda e outros. Recorrida: União Federal (Fazenda Nacional). Relator: Ministro Marco Aurélio. Local, 2009.

BRASIL. Supremo Tribunal Federal. Recurso Extraordinário n. 598.677. Recorrente: Estado do Rio Grande do Sul. Recorrida: Juliana Enderle Fontoura. Relator: Ministro Dias Toffoli. Local, 2009.

BRASIL. Supremo Tribunal Federal. Recurso Extraordinário n. 601.314. Recorrente: Márcio Holcman. Recorrida: União Federal (Fazenda Nacional). Relator: Ministro Ricardo Lewandowski. Local, 2009.

BRASIL. Supremo Tribunal Federal. Recurso Extraordinário n. 601.392. Redatoria Ministro Gilmar Mendes. Recorrente: ECT - Empresa Brasileira de Correios e Telégrafos. Recorrido: Município de Curitiba. Relator: Ministro Gilmar Mendes. Local, 2009.

BRASIL. Supremo Tribunal Federal. Recurso Extraordinário n. 603.191. Recorrente: Construtora Locatelli Ltda. Recorrida: União Federal (Fazenda Nacional). Relatora: Ministra Ellen Gracie. Local, 1999.

BRASIL. Supremo Tribunal Federal. Recurso Extraordinário. 562.276. Recorrente: União Federal (Fazenda Nacional). Recorrido: Owner's Bonés Promocionais Ltda - ME. Relatora: Ministra Ellen Gracie. Local, 2007.

BRASIL. Supremo Tribunal Federal. Súmula n. 323. Local, de 13 de dezembro de 1963.

BRASIL. Supremo Tribunal Federal. Súmula n. 547. Local, de 3 de dezembro de 1969.

BRASIL. Supremo Tribunal Federal. Súmula n. 70, Local, de 13 de dezembro de 1963.

CALMON, Sacha. Teoria geral do tributo e da exoneração tributária. São Paulo: RT, 1982.

CARRAZA, Roque Antônio. Curso de direito constitucional tributário. 25. ed. São Paulo: Malheiros, 2009.

CARVALHO, Paulo de Barros. Curso de direito tributário. 22. ed. São Paulo: Saraiva, 2010.

CARVALHO, Paulo de Barros. Direito tributário: fundamentos jurídicos da incidência. 7. ed. São Paulo: Saraiva, 2009.

COELHO, Sacha Calmon Navarro. Curso de direito tributário brasileiro. 8. ed. Rio de Janeiro: Forense, 2005, p. 876.

COSTA, Nelson Nery. Teoria e realidade da desobediência civil. Rio de Janeiro: Forense, 1990.

DERZI, Misabel. Direito tributário, direito penal e tipo. 2. ed. São Paulo: RT, 2007.

FALCÃO, Amílcar de Araújo. O fato gerador da obrigação tributária. São Paulo: RT, 1973.

FAORO, Raymundo. Os donos do poder: formação do patronato brasileiro. 7. ed. Rio de Janeiro: Globo, 2001.

GAMA, Tácio Lacerda. Competência tributária: fundamentos para uma teoria da nulidade. São Paulo: Noeses, 2009. 
GODOI, Marciano Seabra de. Fraude a la ley y conflicto em la aplicación de las leyes tributarias. Madrid: Instituto de Estudios Fiscales, 2005.

GODOY, Arnaldo Sampaio de Moraes. História da tributação no período joanino: 1808-1821. Brasília: ESAF, 2008

HABERMAS, Jürgen. Direito e democracia: entre facticidade e validade. Trad. Flávio Beno Siebeneichler. Rio de Janeiro: Tempo Brasileiro, 2003.

HOLANDA, Sérgio Buarque de. Raizes do Brasil. 26. ed. São Paulo: Companhia das Letras, 1995.

KELSEN, Hans. A democracia. Trad. Ivone Castilho Benedeti e outros. São Paulo: Martins Fontes, 1993.

KELSEN, Hans. Jurisdição constitucional. 3. ed. São Paulo: Martins Fontes, 2013.

MAGALHÃES, José Luiz Quadros de. Poder municipal: paradigmas para o estado constitucional brasileiro. Belo Horizonte: Del Rey, 1997.

NABAIS, José Casalta. O dever fundamental de pagar impostos: contributo para a compreensão constitucional do estado fiscal contemporâneo. Coimbra: Almedina, 1998.

PEREIRA, Cesar A. Guimarães. Elisão tributária e função administrativa. São Paulo: Dialética, 2001.

POPPER, Karl. A sociedade aberta e seus inimigos. Trad. Milton Amado. São Paulo: Itatiaia, 1987.

PRETA, Stanislaw Ponte. O melhor de Stanislaw Ponte Preta. São Paulo: José Olympio, 2011.

RASPE, Rudolf Erich. As aventuras do barão de Münchhausen. Trad. Ana Goldberger. São Paulo: Iluminuras, 2013.

RAWLS, John. Uma teoria da justiça. Trad. Almiro Piseta e Lenita Esteves. São Paulo: Martins Fontes, 2000.

ROLIM, João Dácio. Normas antielisivas tributárias. São Paulo: Dialética, 2001.

SCHOUERI, Luís Eduardo. Direito Tributário. São Paulo: Saraiva, 2011, p. 519-529.

SHAKESPEARE, William. O mercador de Veneza: 1596. Trad. F. Carlos de Almeida Cunha Medeiros e Oscar Mendes. São Paulo: Martins Fontes, 2006.

SOUSA, Rubens Gomes. Compêndio de legislação tributária. São Paulo: Resenha Tributária, 1975.

SUASSUNA, Ariano. O Auto da Compadecida. 11. ed. Rio de Janeiro: Agir, 1975.

TIPKE, Klaus. Moral tributária do Estado e dos contribuintes. Trad. Luiz Dória Furquim. Porto Alegre: Sergio Antonio Fabriz, 2012.

TORRES, Heleno Taveira. Direito constitucional tributário e segurança jurídica. São Paulo: RT, 2011.

TORRES, Ricardo Lobo. Normas de interpretação e integração do direito tributário. 4. ed. Rio de Janeiro: Renovar, 2006. 
Para publicar na revista Brasileira de Políticas Públicas, acesse o endereço eletrônico www.rbpp.uniceub.br

Observe as normas de publicação, para facilitar e agilizar o trabalho de edição. 